\title{
Dolomitization of the Ordovician subsalt Majiagou Formation in the central Ordos Basin, China: fluid origins and dolomites evolution
}

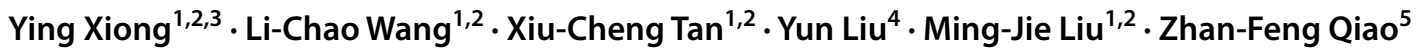

Received: 24 May 2020 / Accepted: 10 August 2020 / Published online: 23 November 2020

(c) The Author(s) 2020

\begin{abstract}
The Middle Ordovician subsalt Majiagou Formation in the Ordos Basin comprises pervasively dolomitized shallow marine limestone and is a major reservoir rich in natural gas resources. Four types of dolomite matrix and cement were identified based on petrographic textures: (very) finely crystalline, non-planar to planar-s matrix dolomite (Md1); finely to medium crystalline, planar-s to planar-e matrix dolomite (Md2); microbialites comprising dolomite microcrystals (Md3); and finely to coarsely crystalline dolomite cement $(\mathrm{Cd})$. The $\mathrm{Md} 1$ and $\mathrm{Md} 2$ dolomites were controlled by alternating lagoon-shoal facies and have $\delta^{13} \mathrm{C}$ values $(-1.89$ to $+1.45 \%$ VPDB for Md1, -1.35 to $+0.42 \%$ VPDB for Md2) that fall within or are slightly higher than the coeval seawater, suggesting the dolomitizing fluid of evaporated seawater. $\mathrm{Md} 2$ dolomite was then subjected to penecontemporaneous karstification by meteoric water and burial recrystallization by sealed brines during diagenesis, as indicated by its relatively lower $\delta^{18} \mathrm{O}$ values $\left(-8.89\right.$ to $-5.73 \%$ o VPDB) and higher ${ }^{87} \mathrm{Sr} /{ }^{86} \mathrm{Sr}$ ratios (0.708920-0.710199). Md3 dolomite comprises thrombolite and stromatolite and is interpreted to form by a combination of initial microbial mediation and later replacive dolomitization related to evaporated seawater. Cd dolomite was associated with early-formed karst system in the $\mathrm{Md} 2$ host dolomite. The lowest $\delta^{18} \mathrm{O}$ values $(-11.78$ to $-10.18 \%$ VPDB) and ${ }^{87} \mathrm{Sr} /{ }^{86} \mathrm{Sr}$ ratios $(0.708688-0.708725)$ and fluid inclusion data $\left(\mathrm{Th}: 123-175{ }^{\circ} \mathrm{C}\right)$ indicate involvement of hydrothermal fluid from which the $\mathrm{Cd}$ dolomite precipitated during deep burial. These results reveal the multi-stage dolomitization history of the Majiagou Formation and provide new constraints on fluid origins and dolomites evolution during deep burial in old superimposed basins, such as the Ordos Basin and elsewhere.
\end{abstract}

Keywords Dolomitization · Fluid origin · Dolomite reservoir · Hydrothermal alteration · Ordos Basin

\section{Introduction}

Edited by Jie Hao

Xiu-Cheng Tan

tanxiucheng70@163.com

1 State Key Laboratory of Oil and Gas Reservoir Geology and Exploitation, Southwest Petroleum University,

Chengdu 610500, Sichuan, China

2 Division of Key Laboratory of Carbonate Reservoirs, CNPC, Southwest Petroleum University, Chengdu 610500, Sichuan, China

3 Institute of Subsurface Energy Systems, Clausthal University of Technology, 38678 Clausthal-Zellerfeld, Germany

4 Research Institute of Petroleum Exploration and Development, PetroChina Southwest Oil and Gas Field Company, Chengdu 610000, Sichuan, China

5 Key Laboratory of Carbonate Reservoir, CNPC, Hangzhou 310023, Zhejiang, China
The origins of dolomites and dolomitizing fluids have been widely investigated. Various models for dolomitization have been proposed to account for the ubiquitous occurrences of dolomite in the geological record, including evaporative, seepage-reflux, mixing zone, burial, hydrothermal, and microbial mechanisms (e.g., Friedman and Sanders 1967; Badiozamani 1973; Hsü and Schneider 1973; Garven et al. 1999; Davies and Smith 2006; Bontognali et al. 2012). The origins of dolomitizing fluids and their migration pathways are among the most hotly debated subjects (Boni et al. 2000; Huang et al. 2014; Wang et al. 2014; Jiang et al. 2016). Due to multiple stages of tectonism and diagenesis, the dolomitization history of the Paleozoic basins of western China is complex and difficult to explain with a single model. Earlyformed dolomite and its geochemical signal are also likely to be overprinted by multiple diagenetic fluids associated 
with a complex burial and tectonic history, which limits our understanding of the deep burial history of dolomite reservoirs.

Due to the abundant gas resources in the Ordos Basin, particularly the subsalt Majiagou Formation reservoir with proven natural gas reserves of $>200 \times 10^{9} \mathrm{~m}^{3}$ (He et al. 2009), numerous studies have been conducted on the Ordovician Majiagou Formation dolomites. A number of models have been proposed, including penecontemporaneous dolomitization (Han and Xin 1995; He et al. 2014), burial dolomitization ( $\mathrm{Su}$ et al. 2011; Chen et al. 2018; Fu et al. 2019), mixed-water dolomitization (Zhao et al. 2005), and localized hydrothermal dolomitization (Wang et al. 2009; Huang et al. 2011). These studies provide important basis for understanding the origins of dolomites in the Majiagou Formation. Nevertheless, most of these studies did not consider the multi-stage evolution and alteration that might have occurred due to multiple and diverse dolomitizing fluids. For example, Yao et al. (2009) and Yang et al. (2018) suggested that the dolomite reservoir in the Majiagou Formation was the product of volume-decreasing dolomitization related to burial brines from Upper Carboniferous strata. However, a relatively closed diagenetic system in a burial environment would appear to be incompatible with the continuous exchange of large quantities of diagenetic fluids, which is the prerequisite for large-scale dolomitization (Warren 2000; Ehrenberg et al. 2012). Burial dolomitization may also be suppressed by existing barriers (e.g., mudstones and evaporites) in moderate-deep burial environments, as these limit the convection or deep circulation of basinal brines (Bjørlykke et al. 1988; Huang et al. 2006). Besides, the relationship between dolomitization and porosity formation is still controversial, as there is currently no convincing evidence showing that porosity directly results from volume-decreasing dolomitization.

This study presents a comprehensive investigation of dolomitizing fluids and dolomites evolution in the multistage diagenetic history of the Ordovician subsalt Majiagou Formation. Detailed petrographic observations, $\mathrm{C}-\mathrm{O}-\mathrm{Sr}$ isotopic data, and fluid inclusion microthermometry data are utilized to: (1) define the dolomite types and their petrological and geochemical characteristics; (2) constrain the origins of the dolomitizing fluids and reconstruct the dolomitization history; (3) determine the exploration targets of the subsalt Majiagou Formation dolomite.

\section{Geological setting}

\subsection{Stratigraphy and depositional setting}

The Ordos Basin is a large superimposed petroliferous basin located in the western North China Block. During the
Middle Ordovician, the Ordos Basin was in a semi-closed epicontinental sea environment (Feng et al. 1999; Hou et al. 2002; Chen et al. 2020) and underwent coeval uplift and subsidence sag (Fig. 1a). The two major tectonic units, which are the Central Uplift and Shanbei Depression, significantly controlled the paleogeography and depositional environment in the central Ordos Basin. Due to compressional tectonic events at the periphery of the North China Block, the basin experienced periodic sea level regressions and evaporatic environments during the Middle Ordovician (Shi et al. 2009; Zhang et al. 2015; Chen et al. 2019). As such, the sedimentary environment of the studied samples was of a semiclosed to evaporatic shallow marine, characterized mainly by intraplatform shoals and restricted-evaporatic lagoons (Fig. 1b) (Liu et al. 2018; Xiao et al. 2019a; Xiong et al. 2020).

Ten sub-members comprise the fifth member of Majiagou Formation (Shi et al. 2009). In particular, the sixth submember (i.e., $\mathrm{Ma5}_{6}$ ) is dominated by massive anhydrite-salt layers that are widely distributed across the whole basin and constitute an important caprock for the subsalt reservoir (i.e., $\mathrm{Ma}_{7}$ to Ma5 10 ). The subsalt Ma5 reservoir is generally characterized by interbedded carbonate and gypsiferous rocks (Fig. 2), corresponding to episodic transgressive-regressive cycles (Chen et al. 2017; Xia et al. 2007; Xiong et al. 2019). The eighth and tenth sub-members were dominantly deposited in a restricted-evaporatic lagoon and comprise gypsiferous rocks interpreted to have been deposited in a dry climate and high salinity conditions. The seventh and ninth submembers consist mainly of carbonate successions deposited during intermittent marine transgressions (Shi et al. 2009; Xie et al. 2013). Intraplatform shoals and microbial mounds occur in the carbonate successions (Fig. 3) and are the most important reservoir rocks (Yao et al. 2009; Liu et al. 2018).

\subsection{Burial history and tectonism}

After deposition of the Majiagou Formation, the basin experienced a protracted burial history and tectonic evolution. Since the Middle Ordovician Caledonian orogeny, the North China Block has been generally uplifted and exposed to a subaerial environment. Intense weathering and erosion of the Ordovician carbonates lasted for ca. $150 \mathrm{Myr}$ (Chen et al. 2020), which led to large-scale karstification (Feng et al. 1999). Thus, large amounts of dissolved pores and vugs were formed in the upper part of Majiagou Formation during this stage. By the late Carboniferous, the North China Block was slowly subsiding and continental-type clastic deposition occurred (Wang and Al-Aasm 2002). The Ordovician carbonates are disconformably overlain by Upper Carboniferous strata. During the Late Jurassic, uplift occurred in the Ordos Basin due to the Yanshanian orogeny and compression in the Qilian tectonic domain, which also led to 


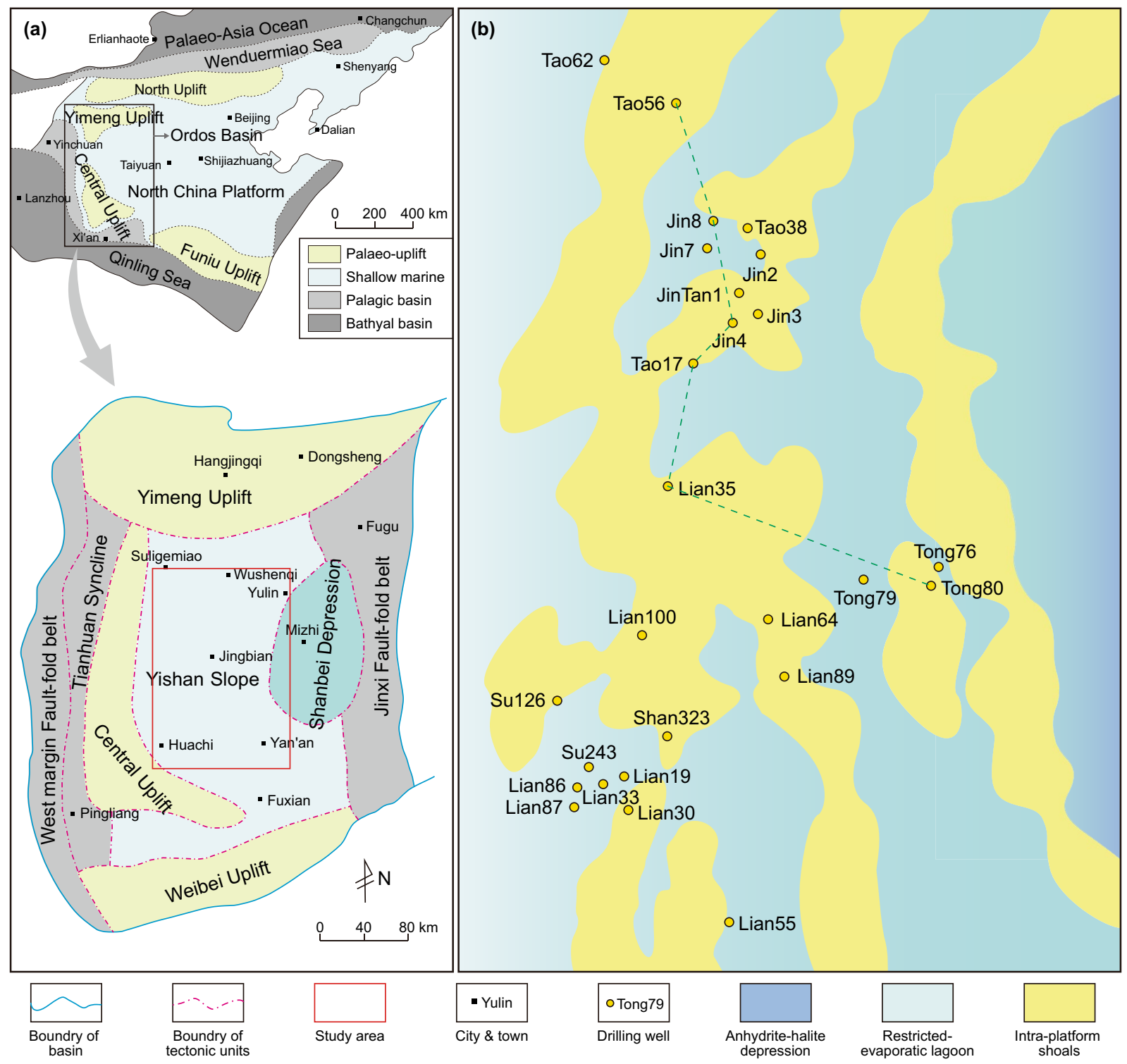

Fig. 1 a Paleogeography of the North China Block and structural map of the Ordos Basin (modified from Chen et al. 2018). The study area is located in the transition zone between the Central Uplift and Shanbei Depression. b Sedimentary facies of the study area during the subsalt Majiagou stage (from Xiong et al. 2019) and the locations of sampled wells. Dashed line indicates the location of stratigraphic cross section shown in Fig. 3

intense magmatism (Yao et al. 2009). During this stage, the Ordovician carbonates were subjected to a new phase of uplift, and three, large-scale, deep fluid upwelling events have been documented at the west margin of Ordos Basin (Wan et al. 2006).

\section{Materials and methods}

This study is based on samples collected from 26 boreholes in the Ordovician subsalt Majiagou Formation in the central Ordos Basin. Petrographic observations were conducted on all core samples and 350 thin sections, which were halfstained with a mixture of Alizarin-red $\mathrm{S}$ and potassium ferricyanide to distinguish calcite and dolomite. Cathodoluminescence (CL) analysis of 30 representative polished thin-sections was undertaken at the School of Geoscience and Technology, Southwest Petroleum University, Chengdu, China, using a CL microscope (Model CL8200 MK5) operated at $7-10 \mathrm{kV}$ and $400-500 \mathrm{~mA}$.

Based on petrographic observations, 59 and 17 microsamples (20-100 $\mathrm{mg}$ ) representing different dolomite types were obtained for stable $\mathrm{C}-\mathrm{O}$ and radiogenic $\mathrm{Sr}$ isotope analyses, respectively. In order to obtain different 


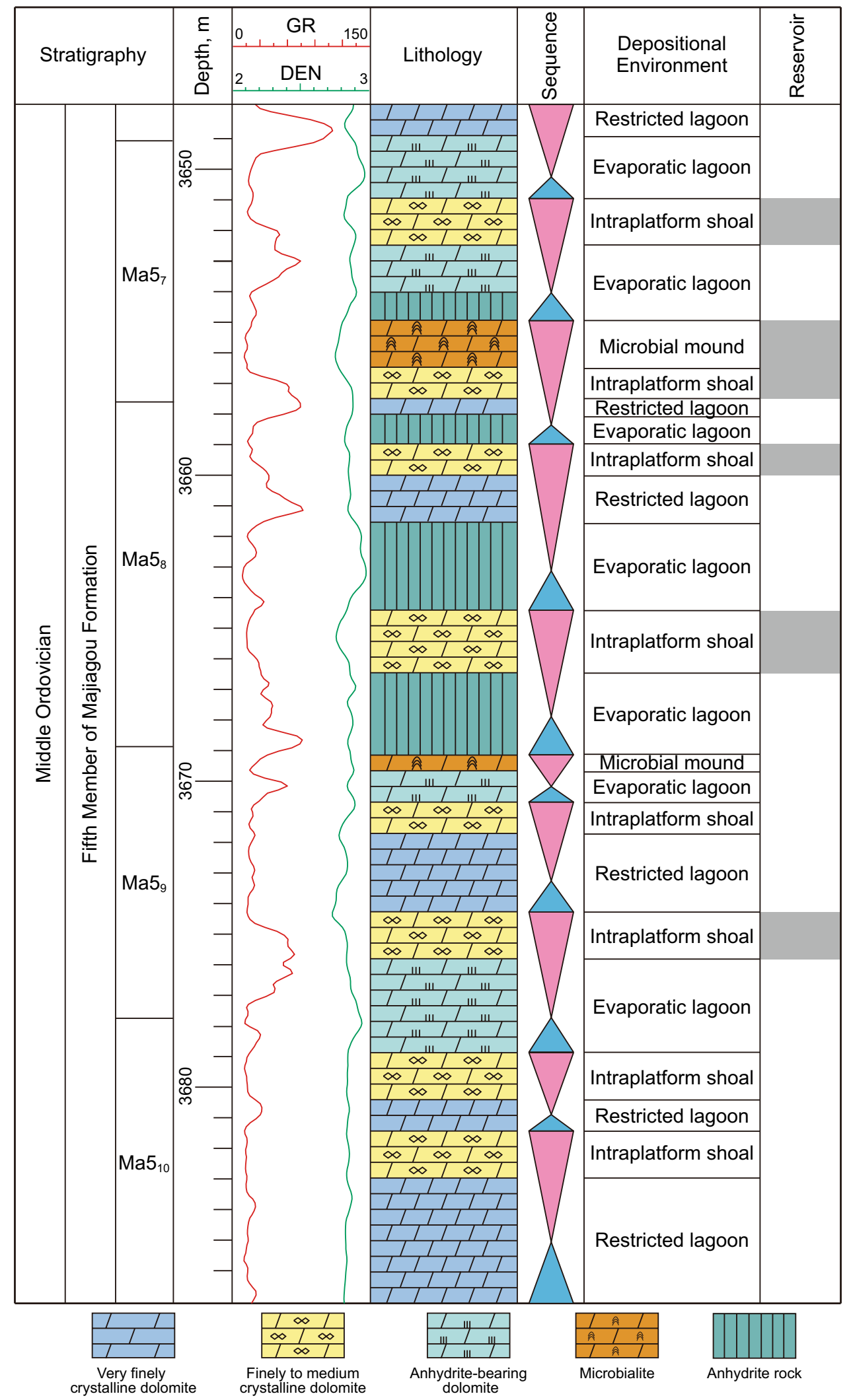

Fig. 2 Lithostratigraphic column, depositional sequence and reservoir description chart of the subsalt Ma5 from well Jintan1. The interpretation of depositional environment was based on Liu et al. (2018) 


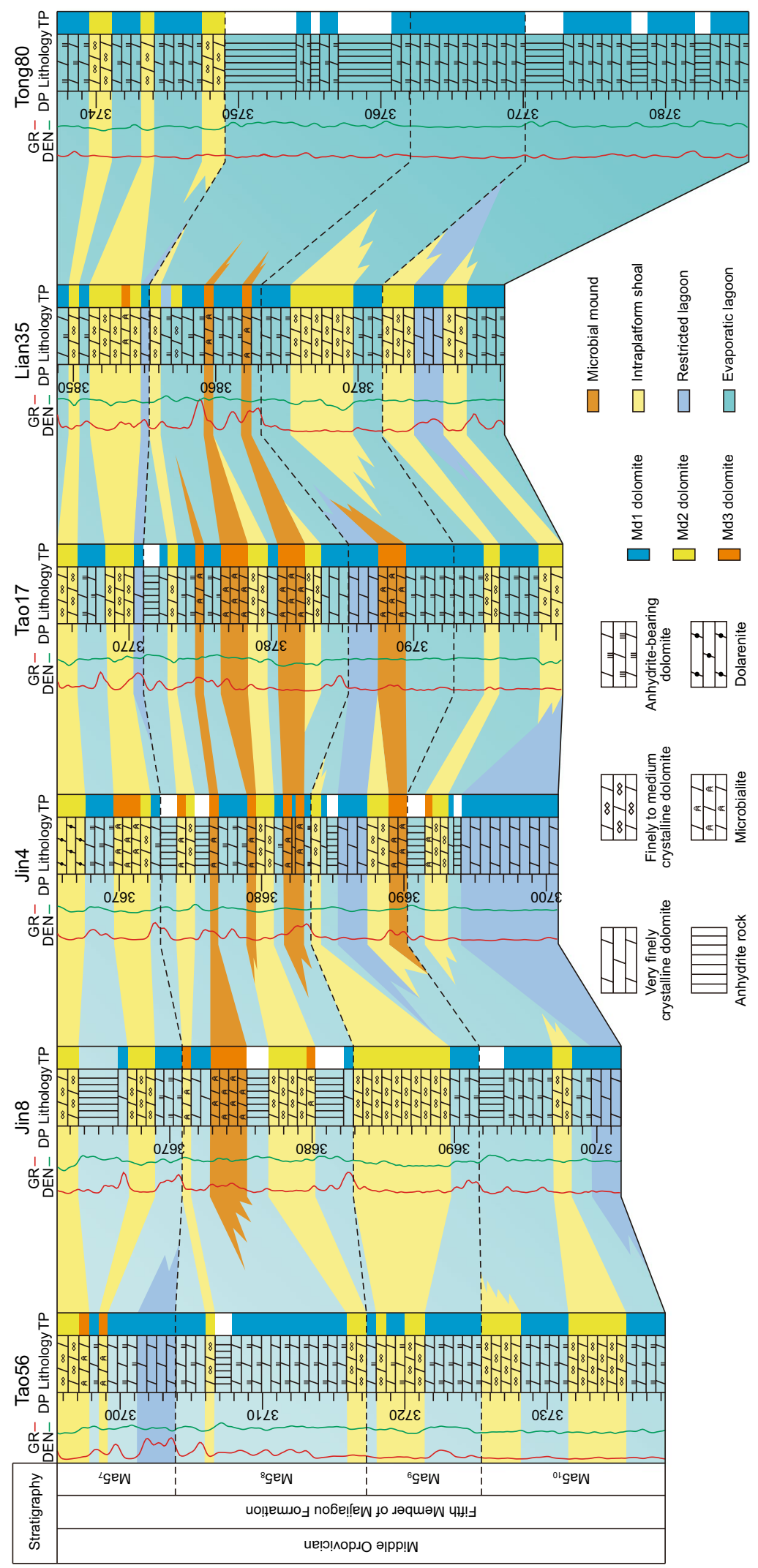

Fig. 3 Cross section of six cored wells showing the distribution of different dolomite types (see classification in the main text) and sedimentary evolution of the subsalt Ma5. The location of cross section is shown in Fig. 1b 
fabrics of the matrix and cement dolomites, a low-speed microdrill (drill bit diameter $<1 \mathrm{~mm}$ ) was used to carefully extract dolomite powders from the fresh core samples. The isotope analyses were undertaken at the Laboratory Center, PetroChina Hangzhou Research Institute of Geology, Hangzhou, China. Dolomite powders for $\delta^{13} \mathrm{C}$ and $\delta^{18} \mathrm{O}$ analysis were reacted with anhydrous phosphoric acid at $72{ }^{\circ} \mathrm{C}$ for $2 \mathrm{~h}$ (Viladkar and Schidlowski 2000), and then, the produced $\mathrm{CO}_{2}$ was analyzed using a Gasbench device connected to a Finnigan Delta V Advantage mass spectrometer. The results are expressed in per mil (\%o) relative to the VPDB standard, and the analytical precision was better than $\pm 0.1 \%$ o $(1 \sigma)$. Dolomite powders for $\mathrm{Sr}$ isotope analysis were dissolved in hydrochloric acid $\left(2.5 \mathrm{~N} \mathrm{HCl} ; 90^{\circ} \mathrm{C}\right)$. Strontium was then separated using conventional ion exchange techniques as described in Weis et al. (2006). ${ }^{87} \mathrm{Sr} /{ }^{86} \mathrm{Sr}$ ratios were measured with a Finnigan TRITON PLUS thermal ionization mass spectrometer. Analytical precision of the Sr isotopic measurements was monitored by repeated analysis of NBS-987 and was better than $\pm 0.000015(2 \sigma)$.

Homogenization temperatures $\left(T_{h}\right)$ of primary fluid inclusions were determined on selected doubly polished thin sections (60 $\mu \mathrm{m}$ thick) at the School of Geoscience and Technology, Southwest Petroleum University, Chengdu, China. The fluid inclusions were analyzed with a Linkam THMSG600 heating-cooling stage, following the methods described in Lu et al. (2017).

\section{Results}

\subsection{Dolomite petrography}

\subsection{1 (Very) finely crystalline, non-planar to planar-s matrix dolomite (Md1)}

This type of dolomite occurs widely in the subsalt Majiagou Formation, but is mostly well-developed in the $\mathrm{Ma}_{8}$ and $\mathrm{Ma}_{10}$ sub-members or in the lower part of meter-scale cycles (Figs. 2, 3). Md1 dolomite is gray to dark gray in color in the cores and has a laminated structure (Fig. 4a). In thin section, Md1 dolomite crystals are 5-50 $\mu \mathrm{m}$ in size, with non-planar to planar-s textures, and are usually associated with evaporite mineral. The anhydrite contents of the rocks are variable, but commonly $5-30$ vol\% (Fig. 4b). Some scattered pyrites occur occasionally associated with the Md1 dolomite (Fig. 4c). Under CL, the Md1 dolomite typically exhibits no to very dull red luminescence (Fig. 4d).

\subsubsection{Finely to medium crystalline, planar-s to planar-e matrix dolomite (Md2)}

$\mathrm{Md} 2$ dolomite occurs mainly in the $\mathrm{Ma}_{7}$ and $\mathrm{Ma}_{9}$ submembers and is distributed in the middle-upper parts of meter-scale cycles (Figs. 2, 3). In core samples, Md2 is light brown to brown-green in color, medium to thick bedded, and not laminated (Fig. 4e). In thin section, the Md2 dolomite has a poikilotopic texture, with euhedral to subhedral crystals that are 50-200 $\mu \mathrm{m}$ in size (Fig. 4f). No evaporite minerals are associated with the $\mathrm{Md} 2$ dolomite. The relatively coarse crystals generally have a cloudy center surrounded by a clear rim, and relict textures of precursor grains are common. Locally, the finely to medium crystalline dolomite crystals are cut by stylolites filled with clay and organic matter. Intercrystalline (dissolved) pores with associated vadose fillings are widely developed in this type of dolomite (Fig. $4 \mathrm{~g}$ ). The Md2 dolomite has a similar very dull red luminescence as Md1 under cold CL, but the overgrowth zoning of $\mathrm{Md} 2$ dolomite crystals is different. The rims display a brighter red luminescence than the interiors of crystals (Fig. 4h).

\subsubsection{Dolomite microcrystals in microbialites (Md3)}

Microbialites are well-developed in the subsalt Ma5 reservoir (Fig. 3) and comprise two types of microbial structures (i.e., thrombolite and stromatolite). Thrombolite is dark brown in the cores (Fig. 4i) and is characterized by the ubiquitous presence of microcrystalline dolomite $(\mathrm{Md} 3)$ in thin-section. These dense sub-micron-sized crystals usually form organic-rich clusters, and the framework structures are commonly infilled by slightly coarser dolomite crystals (microsparry dolomite) (Fig. 4j).

Stromatolite is characterized by regular repetitions of thin layers consisting of two different components, and each growth lamina is generally $\mathrm{mm}$ to $\mathrm{cm}$ thick. Plate-like and small corrugated stromatolites are the most commonly observed types (Fig. 4k). In thin section, the stromatolite laminations comprise alternating layers of dark gray microcrystalline dolomite (Md3) and light gray, (very) finely crystalline dolomite (Fig. 41). The dark layers vary in thickness from 50 to $100 \mu \mathrm{m}$, and the light layers are 200-500 $\mu \mathrm{m}$ thick. Occasional laminated fenestral pores occur between the dark layers.

\subsubsection{Finely to coarsely crystalline dolomite cement (Cd)}

The Cd dolomite consists of 200-2 mm-sized coarse dolomite crystals, which generally occur as infillings of dissolution vugs and fenestral pores in the matrix dolomites. These dolomite crystals are commonly planar euhedral to subhedral, along with some non-planar saddle dolomite with 

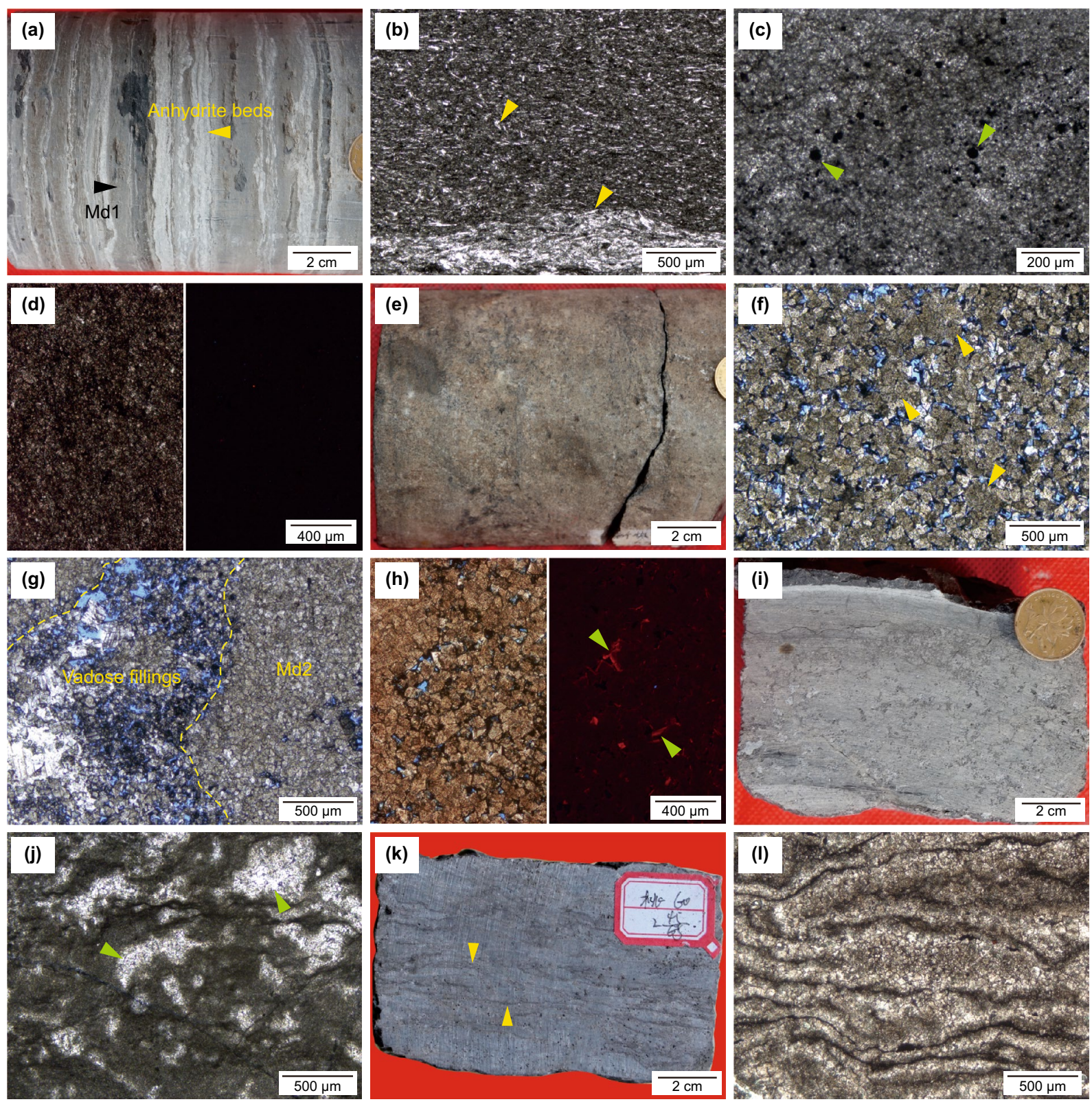

Fig. 4 Petrographic features of matrix dolomite (Md1, Md2 and Md3). a Md1 dolomite intercalated with laminated anhydrite beds, Well J2, $3585.10 \mathrm{~m}$, core. b Md1 dolomite with needle-shaped anhydrite crystals and layers (yellow arrows), Well J2, $3611.25 \mathrm{~m}$, plane-polarized light (PPL). c Scattered pyrite (green arrows) within Md1 dolomite, Well J2, 3602.55 m, PPL. d Coupled optical and cathodoluminescence photomicrographs of Md1 dolomite, showing very dull red luminescence, Well T76, $3725.78 \mathrm{~m}$. e Finely to medium crystalline dolomite (Md2) with thick-bedded structure, Well JT1, $3674.77 \mathrm{~m}$, core. f Finely to medium crystalline dolomite with euhedral to subhedral crystals and welldeveloped intercrystalline pores. Relict textures of precursor grains (yellow arrows) can be vaguely discerned, Well JT1, $3674.64 \mathrm{~m}$, PPL. g Dissolved vugs in Md2 dolomite, half-filled by vadose fillings and coarsely crystalline dolomite cement, Well J2, $3590.76 \mathrm{~m}$, PPL. h Coupled optical and cathodoluminescence photomicrographs of $\mathrm{Md} 2$ dolomite. The mother crystals display very dull red luminescence, while the growth zones (green arrows) show lighter red luminescence, Well JT1, $3674.57 \mathrm{~m}$. i Thrombolite with massive structure, Well J2, $3589.66 \mathrm{~m}$, core. j Framework structure of thrombolite, composed of dense microcrystals (Md3) with bushy clot clusters. The pore network (green arrows) is fullfilled by microsparry dolomite, Well JT1, $3657.09 \mathrm{~m}$, PPL. k Plate-like stromatolite with alternating laminated structure (yellow arrows), WT60, $3483.63 \mathrm{~m}$, core. I Stromatolitic laminae formed of alternating layers of dark gray microcrystalline dolomite (Md3) and light gray microsparry dolomite, Well S310, 4126.54 m, PPL

blade-like terminations or curved crystal surfaces (Fig. 5a, b). These crystals often show strong undulatory extinction under cross-polarized light (Fig. 5b) and display bright red luminescence under CL (Fig. 5c). Besides, minerals such as quartz (Fig. 5d), fluorite (Fig. 5e), and pyrite are also found in the vugs accompanied with $\mathrm{Cd}$ dolomite. 

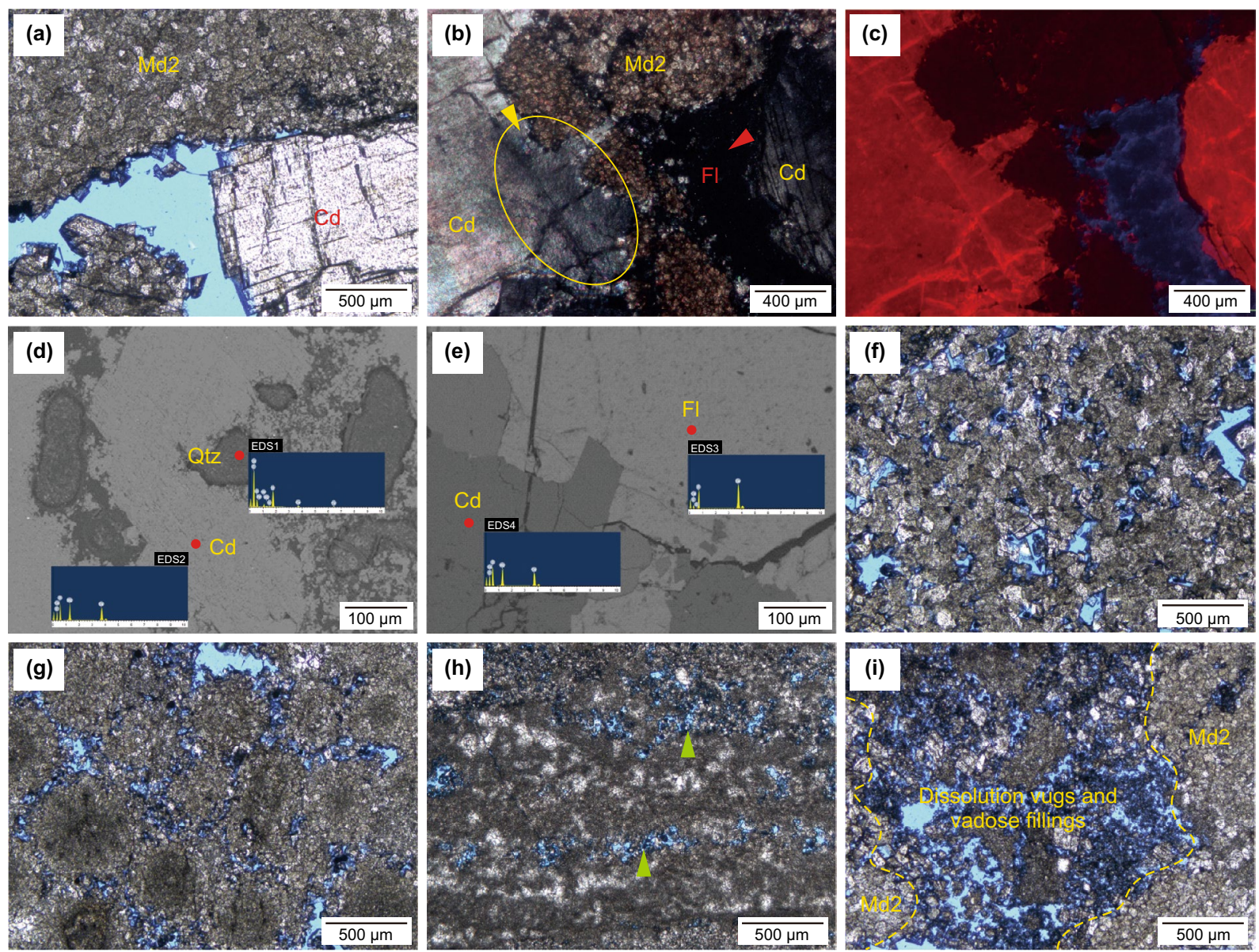

Fig. 5 Petrographic features of cement dolomite (Cd) and pores. a Coarsely crystalline dolomite cement in dissolved vugs, showing planar euhedral crystals, Well T38, 3630.16 m, PPL. b Saddle Cd dolomite and accompanied fluorite. Note the undulatory extinction (yellow arrow) of nonplanar saddle dolomite with curved crystal surfaces and complete extinction of fluorite (red arrow) under cross-polarized light (CPL), Well J2, $3591.14 \mathrm{~m}$. c Coupled cathodoluminescence photomicrograph of c showing dull red luminescence of Md2 dolomite, bright red luminescence of $\mathrm{Cd}$ dolomite and blue luminescence of fluorite. $\mathbf{d}$ Back scattered electron image and energy-dispersive spectrometer (EDS) of Cd dolomite and accompanied quartz (Qtz), Well J4, $3672.8 \mathrm{~m}$. e Back-scattered electron image and energy-dispersive spectrometer of Cd dolomite and accompanied fluorite (Fl), Well J2, $3591.14 \mathrm{~m}$. f Numerous intercrystalline pores in Md2 dolomite, with irregular shapes, Well Tao38, $3630.56 \mathrm{~m}$, PPL. g Intergranular pores in grain dolomite, Well Tao38, $3612.95 \mathrm{~m}$, PPL. h Fenestral pores (green arrows) occur between the dark layers in stromatolite, Well T60, 3483.63 m, PPL. i Dissolved vugs in Md2 dolomite, half-filled by vadose fillings, Well Jin2, 3591.72 m, PPL

\subsection{Pore characteristics}

A variety of pores are present in the studied samples, such as intercrystalline pores (Fig. 5f), intergranular pores (Fig. 5g), fenestral pores (Fig. 5h), and dissolution vugs (Fig. 5i). Intercrystalline pores form the major reservoir space in the subsalt Majiagou Formation and have become the optimal targets for natural gas exploration due to their excellent reservoir capacity. These intercrystalline pores, which are widely developed in the Md2 dolomite, are generally polygonal and $0.1-2.0 \mathrm{~mm}$ in size (Fig. 5f). In contrast to other pores, the intercrystalline pores are mostly well-preserved and have relatively higher porosities of $4-10 \%$. The distribution of intercrystalline pores is closely related to the initial grainstone (Fig. 4f), as shown by the relict textures of precursor grains in the $\mathrm{Md} 2$ dolomite.

\subsection{Geochemistry and microthermometry}

\subsubsection{Carbon and oxygen isotopes}

Carbon and oxygen isotope data for the subsalt Ma5 dolomite are plotted in Fig. 6a and listed in Table 1. Fifty-seven samples of matrix dolomite yielded $\delta^{13} \mathrm{C}$ values from $-1.89 \%$ o to $+1.94 \%$ VPDB (Md1 $=-1.89 \%$ o to $+1.45 \%$, $\mathrm{Md} 2=-1.35 \%$ o to $+0.42 \%$, and $\mathrm{Md} 3=-0.56 \%$ o to $+1.94 \%$ ) and $\delta^{18} \mathrm{O}$ values from $-8.89 \%$ to $-5.73 \%$ o VPDB $(\mathrm{Md} 1=-7.95 \%$ o to $-5.83 \%$, $\mathrm{Md} 2=-8.89 \%$ 。 

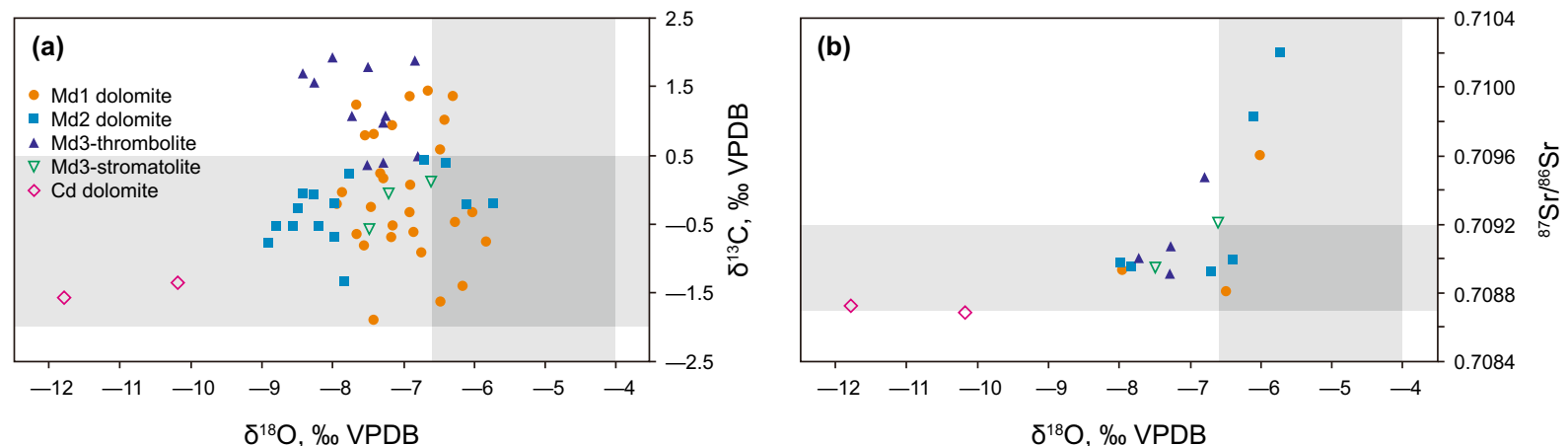

Fig. 6 Isotopic features of different dolomite types. a Cross-plot of $\delta^{13} \mathrm{C}$ and $\delta^{18} \mathrm{O}$ values. b Cross-plot of $\delta^{18} \mathrm{O}$ values and ${ }^{87} \mathrm{Sr} /{ }^{86} \mathrm{Sr}$ ratios. The gray box represent Middle Ordovician marine calcite signature according to Veizer et al. (1999)

to $-5.73 \%$, and $\mathrm{Md} 3=-8.41 \%$ o to $-6.61 \%$ ). $\delta^{13} \mathrm{C}$ values of thrombolite $(+0.37 \%$ to $+1.94 \%$ VPDB; average $=+1.21 \%$; $n=11)$ are significantly higher than those of stromatolite $(-0.56 \%$ o to $+0.12 \%$ VPDB; average $=-0.16 \% \circ ; n=3)$ in the $\mathrm{Md} 3$ dolomite. There were only two samples of dolomite cement available for $\mathrm{C}-\mathrm{O}$ isotope analysis, which yielded $\delta^{13} \mathrm{C}$ values from $-1.56 \%$ o to $-1.36 \%$ VPDB and $\delta^{18} \mathrm{O}$ values from $-11.78 \%$ to $-10.18 \%$ VPDB, respectively, which are lower than the matrix dolomite.

\subsubsection{Strontium isotope}

Fifteen dolomite matrix and two dolomite cement samples analyzed for $\mathrm{C}-\mathrm{O}$ isotopes were also selected for $\mathrm{Sr}$ isotopic analysis (Fig. 6b; Table 1). ${ }^{87} \mathrm{Sr} /{ }^{86} \mathrm{Sr}$ ratios for the matrix dolomite range from 0.708811 from 0.710199 (average $=0.709190 ; n=15)$. Md1 dolomite has ${ }^{87} \mathrm{Sr} /{ }^{86} \mathrm{Sr}=0.708811-0.709605$ (average $=0.709117$; $n=3)$. Md2 dolomite has ${ }^{87} \mathrm{Sr} /{ }^{86} \mathrm{Sr}=0.708920-0.710199$ (average $=0.709310 ; n=6$ ), which tends to be higher than that of Md1 dolomite. Md3 dolomite has ${ }^{87} \mathrm{Sr} /{ }^{86} \mathrm{Sr}=0.708913-0.709474$ (average $=0.709106 ; n=6$ ). ${ }^{87} \mathrm{Sr} /{ }^{86} \mathrm{Sr}$ ratios for dolomite cement vary from 0.708688 to 0.708725 (average $=0.708706 ; n=2$ ), which are lower than those of matrix dolomite.

\subsubsection{Fluid inclusions}

Microthermometry was undertaken on 25 two-phase (liquid-vapor) primary aqueous fluid inclusions in $\operatorname{Md} 2(n=9)$ and Cd dolomite $(n=16)$ (Fig. 7a, b). Fluid inclusions in Md2 dolomite occur mostly along growth zones, while $\mathrm{Cd}$ dolomite has a broader distribution of fluid inclusions in growth zones, clusters, random populations, microfractures, or trails that crosscut crystal boundaries. Fluid inclusions in microfractures and trails were not analyzed, since these inclusions are generally considered to be of secondary origin (Goldstein 2001; Lu et al. 2017). All the analyzed liquid-vapor fluid inclusions have variable shapes (elongate or irregular), are generally $3-10 \mu \mathrm{m}$ in size, and the vapor phase comprises $10-15$ vol\% of the inclusion volumes. Homogenization temperatures $\left(\mathrm{T}_{\mathrm{h}}\right)$ in the $\mathrm{Md} 2$ and $\mathrm{Cd}$ dolomite types vary from 51.5 to $79.8{ }^{\circ} \mathrm{C}$ (average $=66.9{ }^{\circ} \mathrm{C}$; $n=9$ ) and $123-175^{\circ} \mathrm{C}$ (average $=143.2^{\circ} \mathrm{C} ; n=16$ ), respectively (Fig. 7c). Unfortunately, microthermometry was not conducted on the Md1 and Md3 dolomite types, as no liquid-vapor fluid inclusions were found in these dolomite types.

\section{Discussion}

\subsection{Origins of the dolomitizing fluids}

\subsubsection{Md1 dolomite}

Very finely microcrystalline dolomite with anhedral to subhedral texture is commonly linked to penecontemporaneous to near-surface dolomitization at low temperatures (Gregg and Sibley 1984; Warren 2000; Meister et al. 2013; Guo et al. 2016). The Md1 dolomite is laterally continuous and, in some cases, intercalated with laminated anhydrite beds (Figs. 3, 4a), which is consistent with the characteristics of stratiform dolomites formed in evaporatic environments (Warren 2000; Guo et al. 2016; Mahboubi et al. 2016). This also indicates a possible relationship between the dolomitizing fluids and evaporated seawater. The dark red to very dull luminescence of Md1 dolomite was likely to result from extremely low Fe and Mn concentrations in seawater (Xiao et al. 2020).

$\delta^{13} \mathrm{C}$ values of the Md1 dolomite are similar to those of Middle Ordovician seawater $(-2 \%$ to $+0.5 \%$ VPDB; Veizer et al. 1999) (Fig. 6a), suggesting that the dolomitizing fluids originated largely from coeval seawater. Some samples from the $\mathrm{Ma}_{8}$ and $\mathrm{Ma}_{10}$ dolomites have high $\delta^{13} \mathrm{C}$ values 


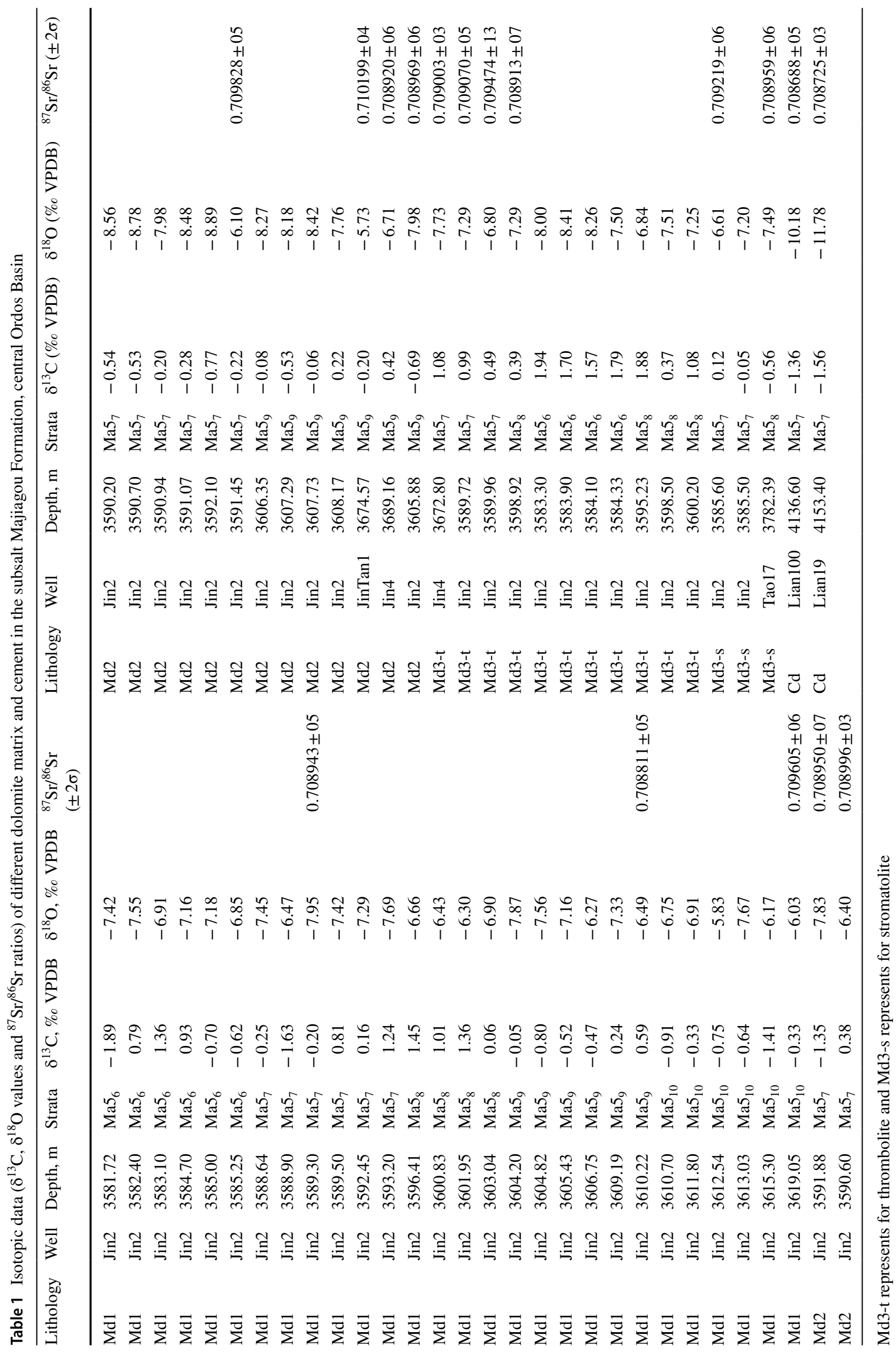



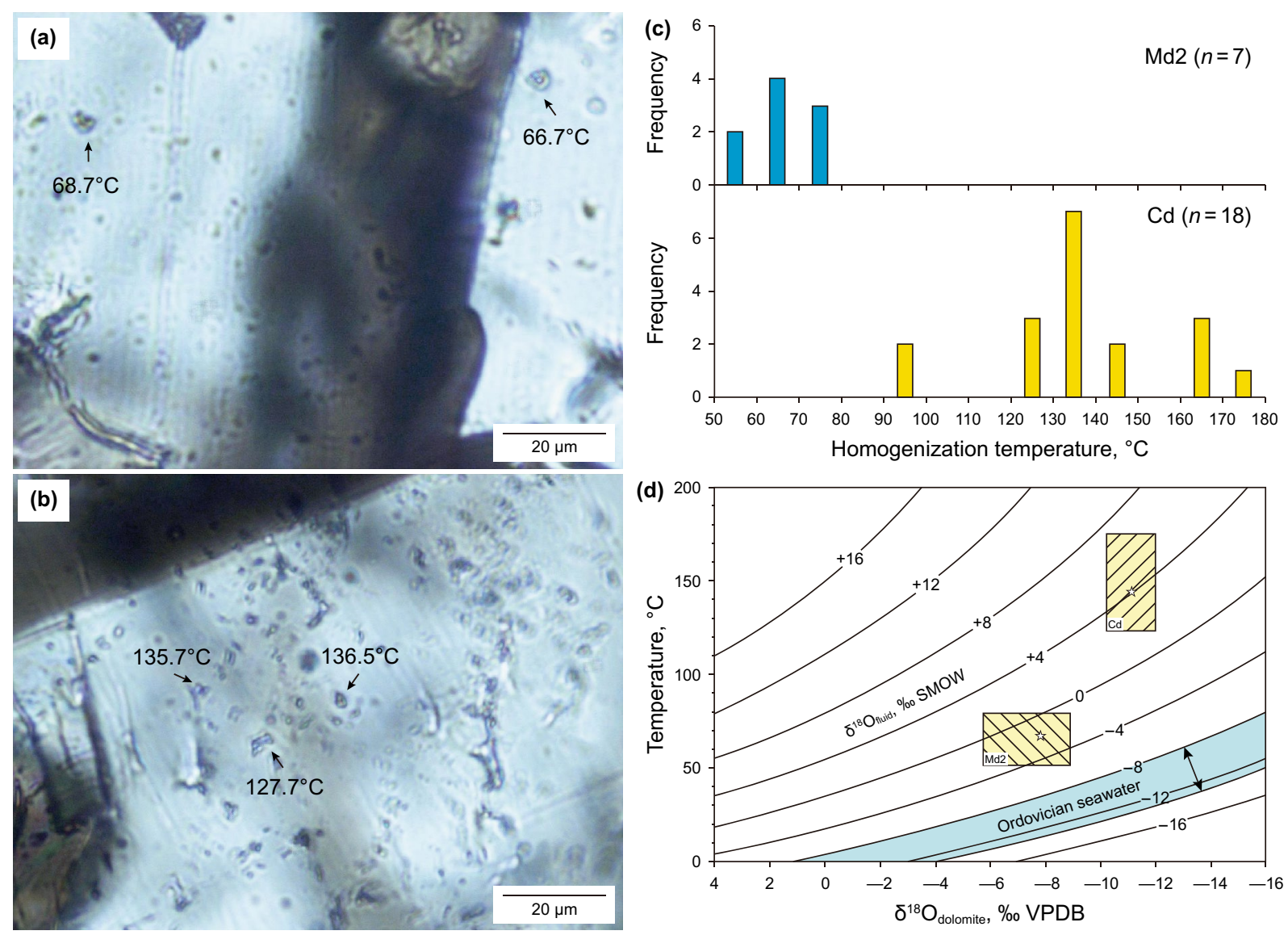

Fig. 7 a, b Photographs of liquid-vapor fluid inclusions in $\mathrm{Md} 2$ dolomite and $\mathrm{Cd}$ dolomite, respectively. c Histogram of fluid inclusion homogenization temperatures $\left(\mathrm{T}_{\mathrm{h}}\right)$ for $\mathrm{Md} 2$ dolomite and $\mathrm{Cd}$ dolomite. d Crossplots of fluid inclusion homogenization temperatures against $\delta^{18} \mathrm{O}$ values for $\mathrm{Md} 2$ dolomite and $\mathrm{Cd}$ dolomite. Temperature versus fluid $\delta^{18} \mathrm{O}$ and dolomite $\delta^{18} \mathrm{O}$ were reconstructed from the equation $10^{3} \ln \alpha_{\text {dolomite-fluid }}=3.2 \times 10^{6} \mathrm{~T}^{-2}-3.3$ (Land 1983). The $\delta^{18} \mathrm{O}_{\text {fluid }}$ values for Ordovician seawater is from Smith (2006). Boxes indicate the range of $\mathrm{T}_{\mathrm{h}}$ and $\delta^{18} \mathrm{O}_{\text {dolomite }}$ values of the $\mathrm{Md} 2$ and $\mathrm{Cd}$ dolomite, and the stars indicate their mean values

and high anhydrite contents, which are likely to be related to evaporated seawater. During these two periods, high-density brine and water stratification caused by evaporation could have formed in a relatively reducing environment near the seawater-sediment interface. In such restricted and oxygendeficient conditions, the degradation of isotopically light carbon from organic matter in the water would have been significantly inhibited (Kelts and Talbot 1990). This results in higher $\delta^{13} \mathrm{C}$ values of the evaporated seawater, as less ${ }^{12} \mathrm{C}$ was released into the water (Nicolaides 1997; Reinhold 1998). $\delta^{18} \mathrm{O}$ values of the Md1 dolomite are slightly lighter as compared with Middle Ordovician seawater $(-6.6 \%$ o to $-4.0 \%$ VPDB; Veizer et al. 1999). This is a widespread feature of many ancient dolomites, which reflects the effect of slightly elevated temperatures on oxygen isotopic fractionation during burial (Nielsen et al. 1994; Guo et al. 2016). Petrographic observations also identified neomorphism of the $\mathrm{Md} 1$ dolomite, as shown by the slightly coarser crystals than modern counterparts, which have dolomite crystals that commonly range in size from 2 to $4 \mu \mathrm{m}$ (Shinn 1983;
Feng et al. 1998). The fluid responsible for Md1 dolomite formation has ${ }^{87} \mathrm{Sr} /{ }^{86} \mathrm{Sr}$ ratios that largely fall within the estimated ${ }^{87} \mathrm{Sr} /{ }^{86} \mathrm{Sr}$ range (0.7087-0.7092) of Middle Ordovician seawater (Veizer et al. 1999) (Fig. 6b). One sample from the $\mathrm{Ma}_{10}$ submember shows a slightly higher ${ }^{87} \mathrm{Sr} /{ }^{86} \mathrm{Sr}$ ratio, which was likely due to the interfusion of terrigenous materials from the Central Uplift, argillaceous dolomite for example (Yang et al. 2018). In general, the Md1 dolomite likely formed from evaporated seawater in a restricted environment.

\subsubsection{Md2 dolomite}

The Md2 dolomite developed mainly in the shoal facies. It is superimposed on the underlying Md1 dolomite and shows regular cyclical sequences (Figs. 2, 3). Its numerous secondary pores and vadose fillings imply a strong influence of meteoric water (Figs. 4g, 5i). In thin sections, the coarsely crystalline, subhedral to euhedral textures contrast with the Md1 dolomite, suggesting a different depositional setting 
or diagenetic process. Some Md2 dolomite crystals are cut by stylolites, indicating that $\mathrm{Md} 2$ dolomite formed before stylolite formation, which is commonly thought to start at a burial depth of ca. 500 m (Mountjoy et al. 1999; Duggan et al. 2001; Fabricius et al. 2007).

$\delta^{13} \mathrm{C}$ values of the $\mathrm{Md} 2$ dolomite fall within the $\delta^{13} \mathrm{C}$ range of Middle Ordovician seawater $(-2.0 \%$ to $+0.5 \%$ o VPDB; Veizer et al. 1999) and largely overlap those of the Md1 dolomite (Fig. 6a), suggesting that the dolomitizing fluid was still seawater-derived fluid. $\delta^{18} \mathrm{O}$ values of the $\mathrm{Md} 2$ dolomite are highly variable and lighter than Middle Ordovician seawater ( $-6.6 \%$ o to $-4.0 \%$ VPDB; Veizer et al. 1999) (Fig. 6a). Given the field and petrographic evidence for karst features and enhanced porosity, the strongly negative $\delta^{18} \mathrm{O}$ values are attributed to intense leaching by meteoric water during the penecontemporaneous karstification (Xiong et al. 2019). This is also supported by the ${ }^{87} \mathrm{Sr} /{ }^{86} \mathrm{Sr}$ ratios of the Md2 dolomite, which partly exceed the ${ }^{87} \mathrm{Sr} /{ }^{86} \mathrm{Sr}$ range (0.7087-0.7092) of Middle Ordovician seawater (Veizer et al. 1999) (Fig. 6b). In addition, intense burial recrystallization can be observed in the $\mathrm{Md} 2$ dolomite, as shown by the relict textures of grains and overgrowths of dolomite crystals. Previous studies have suggested that the burial fluid, comprising concentrated seawater sealed in pores of contemporaneous rocks from the intracratonic depression, has had a strong influence on the petrological features of the porous Md2 dolomite (Chen et al. 2018; Fu et al. 2019). This highlights the influence of multiple diagenetic fluids on the formation of the $\mathrm{Md} 2$ dolomite. The coarsening of crystals and poikilotopic texture likely resulted from crystal overgrowths and subsequent coalescence of crystals, as indicated by the thin lighter CL rims on these dolomite crystals (Fig. 4h). This also suggests a change in the fluids responsible for the later overgrowths.

The average homogenization temperature of liquid-vapor fluid inclusions from growth zones of $\mathrm{Md} 2$ dolomite crystals is $66.9^{\circ} \mathrm{C}$ (Fig. 7c), which is much higher than that of $24.2{ }^{\circ} \mathrm{C}$ from the Majiagou Formation micritic dolomite (equivalent to the $\mathrm{Md} 1$ dolomite) obtained in previous studies (Su et al. 2011). Fluid inclusions reveal that Md2 dolomite probably formed or recrystallized at higher temperatures under shallow burial conditions.

\subsubsection{Md3 dolomite}

Microbialites in the subsalt Majiagou Formation are all dolomite and well-preserved, with typical microbial fabrics such as bonding structures, stromatolitic laminae, and fenestral pores (Figs. 4j, 1, 5h). The framework structure of thrombolites is commonly regarded to be wave-resistant and associated with shoal-deposited grainstones. The laminated structure of stromatolites is interpreted to have been possibly caused by intermittent microbial growth due to diurnal and tidal cycles (Radtke and Golubic 2011). Microbial mediation can facilitate dolomite precipitation because some organic functional groups reduce the hydration of $\mathrm{Mg}^{2+}$ ions that inhibits nucleation of dolomite from $\mathrm{Mg}$ supersaturated brines (Mazzullo 2000; Warthman et al. 2000; Dupraz and Visscher 2005; Wolicka and Borkowski 2011). However, the model for microbial dolomitization has been recently criticized and is thought to be inappropriate for large-scale dolomitization (Petrash et al. 2017). According to a close examination and cation ordering comparison of published X-ray data for microbial-mediated carbonates synthesized during laboratory experiments, Gregg et al. (2015) and Kaczmarek et al. (2017) argued that most of the products are very high$\mathrm{Mg}$ calcite rather than dolomite as claimed previously, since these products lack dolomite 'ordering' reflections.

In general, the formation mechanisms of microbialites comprise several processes: microbial capturing and bonding, microbial mineralization, in situ precipitation of carbonate, and post-depositional processes (Andres and Reid 2006; Hips et al. 2015). In the studied subsalt Majiagou Formation, the carbonate sediments have been pervasively dolomitized, and no direct evidence of microbial dolomitization has been found, such as sub-micron-sized spheroidal structures and dumbbell-shaped dolomite (Dupraz et al. 2009; Perri and Tucker 2015). In addition, abundant microbialites of limestone are found above the salt layer in this area (i.e., $\mathrm{Ma}_{5}$ ) (Meng et al. 2019). These characteristics indicate that there is no direct correspondence between microbial mediation and dolomite content. The initial product of microbial mediation was likely to be calcite (or high-Mg calcite) precursor, which was then subjected to replacive dolomitization driven by high-salinity seawater and evaporation. Thus, the isotopic signatures of $\mathrm{Md} 3$ dolomite were inherited from the combined effects of both microbial mediation and evaporated seawater. $\delta^{13} \mathrm{C}$ values of the thrombolites are slightly higher than those of the stromatolites (Fig. 6a), which might result from two different microbial induction mechanisms. To be specific, microbes, such as cyanobacteria, preferentially absorbed the ${ }^{12} \mathrm{CO}_{2}$ from the ambient environment when they synthesized organics through photosynthesis, which contributed to enriched ${ }^{12} \mathrm{C}$ in the synthesized organics. Correspondingly, the carbonates precipitated from seawater were ${ }^{13} \mathrm{C}$-rich. Whereas, other microbes, such as sulfate reducing bacteria, produced and released more ${ }^{12} \mathrm{CO}_{2}$ into ambient seawater by sulfate reduction of organics, which ultimately resulted in lower $\delta^{13} \mathrm{C}$ values of the carbonate sediments (Irwin et al. 1977; Preuss et al. 1989; Warren 2000). However, the gap in $\delta^{13} \mathrm{C}$ values between these two sediment types has been narrowed or overprinted by later refluxing of evaporated seawater. $\delta^{18} \mathrm{O}$ values of stromatolites and thrombolites are highly similar with those of Md1 and Md2 dolomites, respectively (Fig. 6a), which is consistent with the distribution that stromatolites developed in lagoon and 
thrombolites associated with shoal-mound facies. The relatively lower $\delta^{18} \mathrm{O}$ values of thrombolites than stromatolites indicate relatively high positions of microbial mounds that were more likely to exposed and leached by meteoric water. ${ }^{87} \mathrm{Sr} /{ }^{86} \mathrm{Sr}$ ratios of the $\mathrm{Md} 3$ dolomite largely fall within the estimated ${ }^{87} \mathrm{Sr} /{ }^{86} \mathrm{Sr}$ range of the coeval seawater (Fig. 6b), also suggesting the seawater-sourced dolomitizing fluid responsible for $\mathrm{Md} 3$ dolomite.

\subsubsection{Cd dolomite}

The finely to coarsely crystalline dolomite cement commonly infills dissolution pores and vugs (Fig. 5a), suggesting that its formation was associated with previous karst systems. The coarse dolomite crystals with curved surfaces and undulatory extinction under cross-polarized light (Fig. 5b) typically reflect rapid crystallization and precipitation under higher temperature conditions (Guo et al. 2016; Feng et al. 2017). The very bright luminescence contrasts with the matrix dolomite and implies a different dolomitization fluid with a higher concentration of $\mathrm{Mn}$ ions at higher temperatures (Fig. 5c). Minerals such as fluorite, quartz, and pyrite, which are associated with the $\mathrm{Cd}$ dolomite, also indicate a hydrothermal process (Fig. 5d, e). The relatively lower $\delta^{18} \mathrm{O}$ values (Fig. 6a) and higher homogenization temperatures of Cd dolomite (Fig. 7c) relative to matrix dolomite indicates late-stage precipitation at high temperatures during deep burial. Besides, its lower ${ }^{87} \mathrm{Sr} /{ }^{86} \mathrm{Sr}$ ratios (Fig. 6b) as compared with the matrix dolomite indicate possible involvement of ${ }^{87} \mathrm{Sr}$-depleted, mantle-sourced fluids.

To determine the $\delta^{18} \mathrm{O}_{\text {fluid }}$ compositions of the $\mathrm{Md} 2$ and $\mathrm{Cd}$ dolomites, $\delta^{18} \mathrm{O}$ values were plotted versus $\mathrm{T}_{\mathrm{h}}$ (Fig. 7d). The calculated $\delta^{18} \mathrm{O}_{\text {fluid }}$ for $\mathrm{Md} 2$ dolomite ranges from $-6.0 \%$ o to $+2.0 \%$ o (relative to $\mathrm{V}-\mathrm{SMOW}$ ) and for $\mathrm{Cd}$ dolomite from $+1.5 \%$ to $+7.5 \%$ V-SMOW. Given that evaporated seawater near the gypsum saturation state would be $3 \% \circ \pm 1 \%$ enriched in $\delta^{18} \mathrm{O}$ relative to contemporaneous seawater (Gonfiantini 1986), then the evaporated Ordovician seawater would have $\delta^{18} \mathrm{O}=-10 \%$ o to $-5 \%$ o V-SMOW (Smith 2006; Wang et al. 2009), close to that of the calculated $\delta^{18} \mathrm{O}_{\text {fluid }}$ for Md2 dolomite. Hence, concentrated Ordovician seawater could have supplied the initial dolomitizing fluid for the $\mathrm{Md} 2$ dolomite. There are strong similarities and overlap between the $\delta^{18} \mathrm{O}_{\text {fluid }}$ values of the Cd dolomite and the estimated values for magmatic fluids (+5.5\%o to $+10.0 \%$ o-SMOW; Taylor 1997). This suggests that fluids with hydrothermal sources, possibly magmatic fluids, were involved in the formation of the Cd dolomite.

\subsection{Dolomitization history and dolomites evolution}

Combining our results and their implications with the depositional setting and burial history of the study area (Fig. 8),

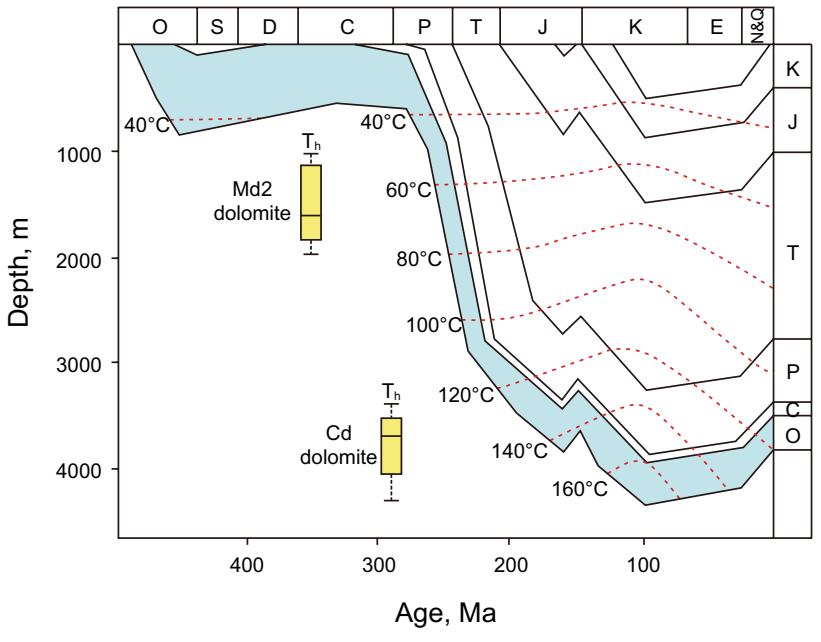

Fig. 8 Burial history of the Ordovician strata in the Ordos Basin based on well Tainsheg1 and homogenization temperatures ranges of two types of dolomite (see classification in the main text). The burial history is modified form Wang and Al-Aasm (2002) and Xiao et al. (2019b)

a multi-stage dolomitization model was proposed to explain the formation and evolution of dolomites in the subsalt Majiagou Formation (Fig. 9).

During the Middle Ordovician, the study area was a restricted-evaporatic carbonate platform, in which the circulation of seawater was greatly restricted (Chen et al. 2018; Liu et al. 2019). In such a geographic setting, a warm, semiarid to arid climate could have enhanced evaporation and resulted in elevated salinity of the seawater. The primary limestone sediments in the lagoon and shoal facies were likely replaced when highly saline seawater infiltrated and migrated downslope (Fig. 9a). Precipitation of gypsum would increase the $\mathrm{Mg} / \mathrm{Ca}$ ratios of bottom waters, which also promoted dolomitization. Sea level fluctuations during this stage (Bai et al. 2016; Xi et al. 2017; Liu et al. 2018) controlled the depositional sequence of lagoon-shoal facies and water exchange between the platform interior and the open marine environment. This facilitated continuous dolomitization and alternation of $\mathrm{Md} 1$ and $\mathrm{Md} 2$ dolomites (Fig. 2). In general, a seepage-reflux dolomitization model could explain the initial replacement of the underlying limestone sediments by Md1 and Md2 dolomites. Meanwhile, near the sediment-water interface, microbial mediation and early dolomitization driven by highly saline seawater could also facilitate the formation of Md3 dolomite. The initial fenestral pores, developed between the thrombolitic clots and stromatolitic dark layers, were then cement-filled by microsparry dolomite during penecontemporaneous to shallow burial setting.

Since the late Carboniferous, the North China Block have slowly subsided after a long period of subaerial exposure, 
(a) Near-surface to very shallow burial (Middle Ordovician)

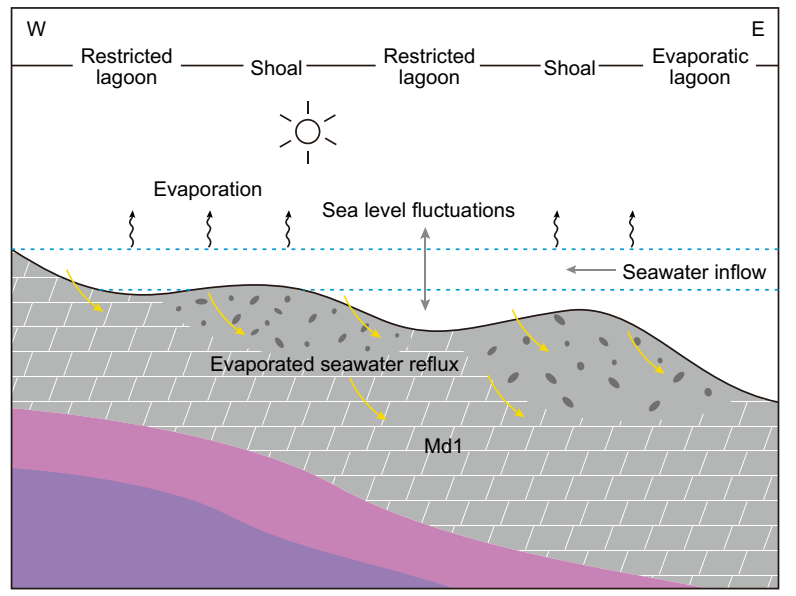

(c) Shallow-medium burial (Late Carboniferous - Jurassic)
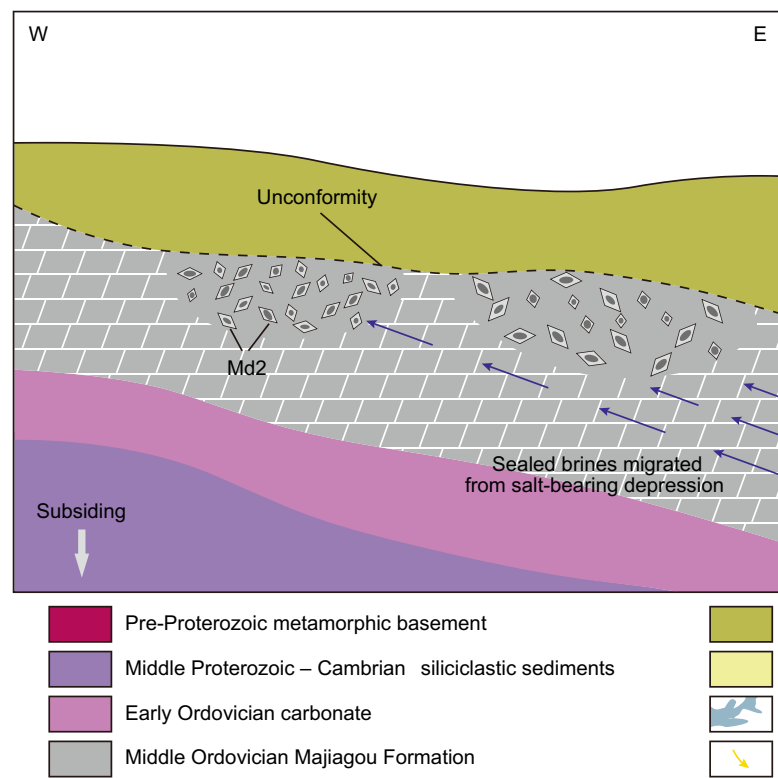

(b) Penecontemporaneous exposure

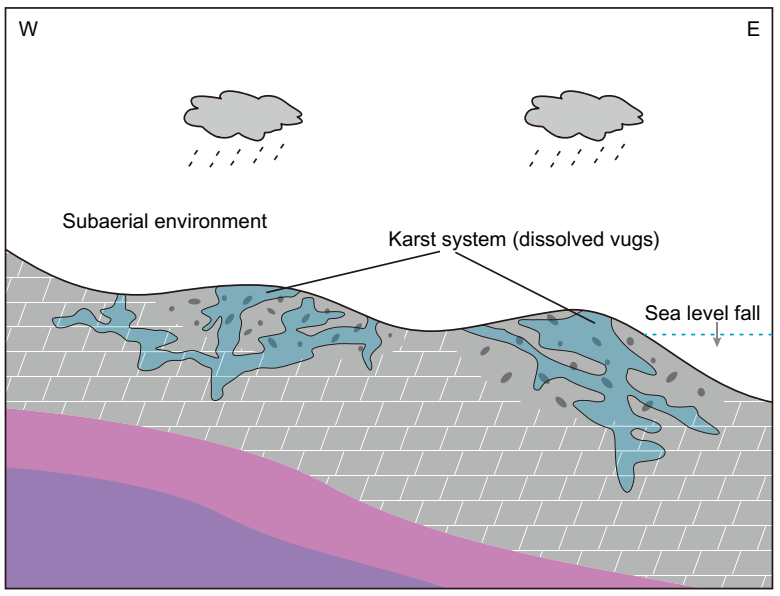

(d) Deep burial (Late Jurassic)

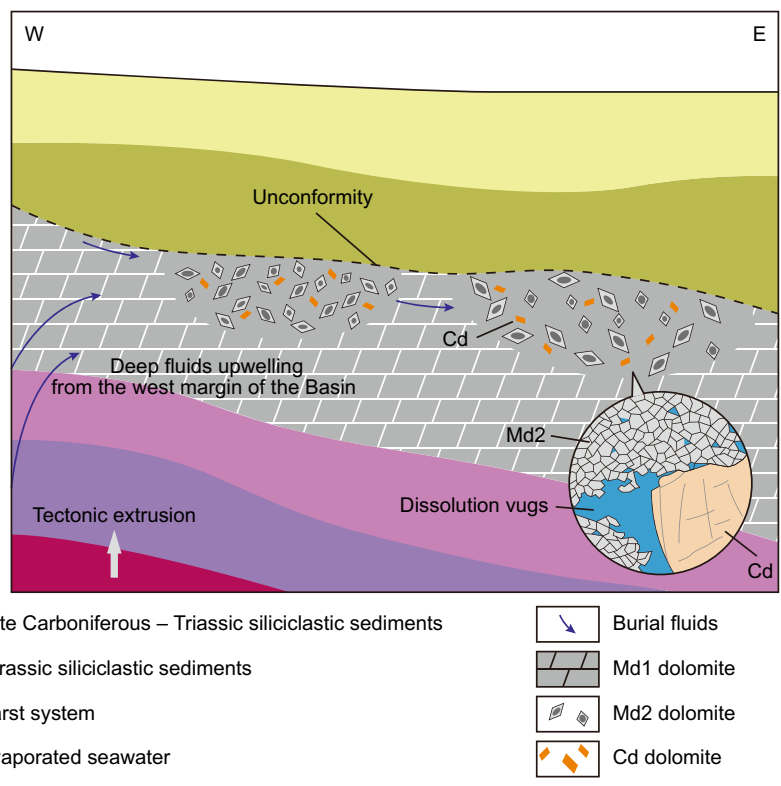

Fig. 9 Conceptual model of multi-stage dolomitization history in the Ordovician Majiagou Formation. a Lagoon-shoal facies deposits were initially dolomitized during near-surface to very shallow burial, related to evaporated seawater reflux. b The shoal facies grainstone was exposed to subaerial environment and subjected to penecontemporaneous karstification. $\mathbf{c}$ Md2 dolomite was modified in the middle diagenetic stage (recrystallization and overgrowth by burial brines migrated from the salt-bearing depression). d Hydrothemal alternation and cement-filling within early-formed karst vugs in Md2 dolomite during the late stage

and the subsalt Majiagou Formation underwent burial diagenesis, with gradual increases in temperature and pressure. A large amount of Mg-rich fluids sealed in the saltbearing depression (eastern Ordos Basin) were released and then migrated into the high porosity-permeability layers in the central Ordos Basin. The Md2 dolomite, which developed in shoal facies, preserved abundant dissolved pores and vugs that could provide flow pathways for burial diagenetic fluids (Fig. 9b). Thus, the high salinity sealed brines preferentially migrated into the porous $\mathrm{Md} 2$ dolomite. Consequently, intense recrystallization occurred in the shoal facies dolomite, and the doloarenites were transformed into crystalline dolomites with more ideal crystal shapes (Fig. 9c). The estimated depth for recrystallization varies from 1150 to $1800 \mathrm{~m}$, based on its homogenization temperatures and the burial history in this area (Fig. 8).

During the Late Jurassic, the Ordovician carbonates were subjected to a new stage of uplift due to the Yanshanian orogeny and compression in the Qilian tectonic domain. Intense magmatic activities and deep fluid upwelling events occurred at the west margin of Ordos Basin (Wan et al. 2006). These deep-sourced fluids could have migrated into the basin along basement faults, as well as via unconformities (Yao et al. 2009). According to the occurrence and 
distribution of Cd dolomite, fluid flow within the Majiagou Formation was controlled by preexisting high-porosity-permeability layers. Thus, the $\mathrm{Md} 2$ dolomite, with abundant dissolved pores and vugs formed by early karstification, provided favorable fluid migration pathways for the dolomitizing fluids. The primary hydrothermal fluid caused dissolution along fractures and in early-formed dissolution vugs, while then became progressively enriched in $\mathrm{Mg}^{2+}$. Once the $\mathrm{Mg}^{2+}$ concentrations reached the saturation threshold for dolomite, $\mathrm{Cd}$ dolomite would have been precipitated in these pores and vugs, in the form of cement (Fig. 9d). The estimated forming depth for Cd dolomite is $3500-4100 \mathrm{~m}$ (Fig. 8). Therefore, karst-controlled hydrothermal alteration can explain the formation of Cd dolomite. Similar hydrothermal dolomitization controlled by early karst systems has been reported worldwide (Beckert et al. 2016; Liu et al. 2016; Xiao et al. 2016; Garaguly et al. 2018).

\section{Conclusions}

The Ordovician subsalt Majiagou Formation was deposited on a shallow marine platform in the Ordos Basin and has been pervasively dolomitized. Four types of dolomite matrix and cement were identified: (very) finely crystalline, nonplanar to planar-s matrix dolomite (Md1); finely to medium crystalline, planar-s to planar-e matrix dolomite (Md2); dolomite microcrystals in microbialites (Md3); finely to coarsely crystalline dolomite cement $(\mathrm{Cd})$.

Md1 dolomite is commonly associated with evaporite mineral and has isotopic features similar to the Middle Ordovician seawater, and formed from evaporated seawater in a near-surface setting. Md2 dolomite, with lower $\delta^{18} \mathrm{O}$ and higher ${ }^{87} \mathrm{Sr} /{ }^{86} \mathrm{Sr}$ values than $\mathrm{Md} 1$ dolomite, was initially dolomitized by evaporated seawater reflux during very shallow burial and then subjected to dissolution and burial recrystallization, which formed abundant intercrystalline porosity. Md3 dolomite resulted from a combination of initial microbial mediation and later replacive dolomitization related to evaporated seawater. The Cd dolomite has the lowest $\delta^{18} \mathrm{O}$ values and highest homogenization temperatures and was likely precipitated from hydrothermal fluids during deep burial.

The Md2 and Md3 dolomites, which were controlled by shoal-mound facies, karstification, and recrystallization, are the major reservoir rocks in the subsalt Majiagou Formation, although part of the porosity was infilled by $\mathrm{Cd}$ dolomite.

Acknowledgements This study was supported by the National Science and Technology Major Projects of China (Grant Nos. 2016ZX05004006-001-002 and 2016ZX05004002-001), PetroChina Science and Technology Project (Grant No. 2019B-0406) and the China Scholarship Council (No. 201908080005). We thank Professor Ling Li, Dr. Di Xiao for their advice regarding our manuscript.
Open Access This article is licensed under a Creative Commons Attribution 4.0 International License, which permits use, sharing, adaptation, distribution and reproduction in any medium or format, as long as you give appropriate credit to the original author(s) and the source, provide a link to the Creative Commons licence, and indicate if changes were made. The images or other third party material in this article are included in the article's Creative Commons licence, unless indicated otherwise in a credit line to the material. If material is not included in the article's Creative Commons licence and your intended use is not permitted by statutory regulation or exceeds the permitted use, you will need to obtain permission directly from the copyright holder. To view a copy of this licence, visit http://creativecommons.org/licenses/by/4.0/.

\section{References}

Andres MS, Reid RP. Growth morphologies of modern marine stromatolites; a case study from Highborne Cay. Bahamas Sediment Geol. 2006;185:319-28. https://doi.org/10.1016/j.sedge o.2005.12.020.

Badiozamani K. The Dorag dolomitization model, application to the middle Ordovician of Wisconsin. J Sediment Res. 1973;43:96584. https://doi.org/10.1306/74D728C9-2B21-11D7-8648000102 C1865D.

Bai XL, Zhang SN, Huang QY, et al. Origin of dolomite in the Middle Ordovician peritidal platform carbonates in the northern Ordos Basin, western China. Pet Sci. 2016;13(3):434-49. https ://doi.org/10.1007/s12182-016-0114-5.

Beckert J, Vandeginste V, Cédric MJ. Relationship between karstification and burial dolomitization in Permian platform carbonates (lower khuff-oman). Sed Geol. 2016;342:165-79. https://doi. org/10.1016/j.sedgeo.2016.07.001.

Bjørlykke K, Mo A, Palm E. Modelling of thermal convection in sedimentary basins and its relevance to diagenetic reactions. Mar Pet Geol. 1988;5:338-51. https://doi.org/10.1016/02648172(88)90027-X.

Boni M, Parente G, Bechstädt T, et al. Hydrothermal dolomites in SW Sardinia (Italy): evidence for a widespread Late-Variscan fluid flow event (in Paleofluid flow and diagenesis during basin evolution). Sed Geol. 2000;131:181-200. https://doi. org/10.1016/0264-8172(88)90027-X.

Bontognali TR, Vasconcelos C, Warthmann RJ, et al. Dolomitemediating bacterium isolated from the sabkha of Abu Dhabi (UAE). Terra Nova. 2012;24:248-54. https://doi.org/10.111 1/j.1365-3121.2012.01065.x.

Chen AQ, Xu SL, Yang S, et al. Ordovician deep dolomite reservoirs in the intracratonic Ordos Basin, China: depositional model and diagenetic evolution. Energy Explor Exploit. 2018;36(4):85071. https://doi.org/10.1177/0144598718778171.

Chen AQ, Yang S, Chen HD, et al. The sedimentary filling model of epeiric platform and new inspiration of innercratonic carbonate for oil \& gas exploration. Acta Pet Sin. 2017;33(4):1243-56 (in Chinese).

Chen AQ, Yang S, Xu SL, et al. Sedimentary model of marine evaporites and implications for potash deposits exploration in China. Carbonates Evaporites. 2019;34(1):83-99. https://doi. org/10.1007/s13146-018-0443-0.

Chen AQ, Zou H, Ogg JG, et al. Source-to-sink of Late Carboniferous Ordos Basin: constraints on crustal accretion margins converting to orogenic belts bounding the North China Block. Geosci Front. 2020;11(6):2031-52. https://doi.org/10.1016/j.gsf.2020.05.008.

Davies GR, Smith LB Jr. Structurally controlled hydrothermal dolomite reservoir facies: an overview. AAPG Bull. 2006;90:164190. https://doi.org/10.1306/05220605164. 
Duggan JP, Mountjoy EW, Stasiuk LD. Fault-controlled dolomitization at Swan Hills Simonette oil field (Devonian), deep basin west-central. Alberta, Canada. Sedimentology. 2001;48:301-23. https://doi.org/10.1046/j.1365-3091.2001.00364.x.

Dupraz C, Reid RP, Braissant O, et al. Processes of carbonate precipitation in modern microbial mats. Earth Sci Rev. 2009;96:14162. https://doi.org/10.1016/j.earscirev.2008.10.005.

Dupraz C, Visscher PT. Microbial lithification in marine stromatolites and hypersaline mats. Trends Microbiol. 2005;13:429-38. https://doi.org/10.1016/j.tim.2005.07.008.

Ehrenberg SN, Walderhaug O, Bjorlykke K. Carbonate porosity cretation by mesogenetic dissolution: reality or illusion? AAPG Bull. 2012;97:345-345. https://doi.org/10.1306/05031110187.

Fabricius IL, Borre MK. Stylolites, porosity, depositional texture, and silicates in chalk facies sediments. Ontong Java PlateauGorm and Tyra fields, North Sea. Sedimentology. 2007;54:183205. https://doi.org/10.1111/j.1365-3091.2006.00828.x.

Feng MY, Wu PC, Qiang ZT, et al. Hydrothermal dolomite reservoir in the Precambrian Dengying Formation of central Sichuan Basin, southwestern China. Mar Pet Geol. 2017;82:206-19. https://doi. org/10.1016/j.marpetgeo.2017.02.008.

Feng ZZ, Bao ZD. Lithofacies paleogeography of Majiagou age of Ordovician in Ordos Basin. Acta Sedimentol Sin. 1999;17(1):1-8 (in Chinese).

Feng ZZ, Zhang YS, Jin ZK. Type, origin, and reservoir characteristics of dolostones of the Ordovician Majiagou Group, Ordos, North China. Platform Sediment Geol. 1998;118:127-40. https://doi. org/10.1016/S0037-0738(98)00009-8.

Friedman GM, Sanders JE. Origin and occurrence of dolostones. In: Chilingar GV, Bissell HJ, Fairbridge RW, editors. Developments in sedimentology: carbonate rocks origin, occurrence and classification. Amsterdam: Elsevier; 1967. p. 267-348. https://doi. org/10.1016/S0070-4571(08)71114-2.

Fu SY, Zhang CG, Chen HD, et al. Characteristics, formation and evolution of pre-salt dolomite reservoirs in the fifth member of the Ordovician Majiagou Formation, mid-east Ordos Basin, NW China. Pet Exp Dev. 2019;46(6):1153-64. https://doi.org/10.1016/ S1876-3804(19)60270-3.

Garaguly I, Andrea V, Raucsik B, et al. Pervasive early diagenetic dolomitization, subsequent hydrothermal alteration, and late stage hydrocarbon accumulation in a middle Triassic carbonate sequence (Szeged basin, SE Hungary). Mar Pet Geol. 2018;98:270-90. https://doi.org/10.1016/j.marpe tgeo.2018.07.024.

Garven G, Appold MS, Toptygina VI, et al. Hydrogeologic modeling of the genesis of carbonate-hosted lead-zinc ores. Hydrogeol J. 1999;7:108-26. https://doi.org/10.1007/s100400050183.

Gonfiantini R. Environmental isotopes in lake studies. In: Fritz P, Fontes JC, editors. Handbook of environmental isotope geochemistry. Amsterdam: Elsevier; 1986. p. 113-68.

Goldstein RH. Fluid inclusions in sedimentary and diagenetic systems. Lithos. 2001;55(1-4):159-93. https://doi.org/10.1016/S0024 -4937(00)00044-X.

Gregg JM, Sibley DF. Epigenetic dolomitization and the origin of xenotopic dolomite texture. J Sediment Res. 1984;54:908-31. https ://doi.org/10.1306/212F8535-2B24-11D7-8648000102C1865D.

Gregg JM, Bish DL, Kaczmarek SE, et al. Mineralogy, nucleation and growth of dolomite in the laboratory and sedimentary environment: a review. Sedimentology. 2015;62(6):1749-69. https://doi. org/10.1111/sed.12202.

Guo C, Chen DZ, Qing HR, et al. Multiple dolomitization and later hydrothermal alteration on the Upper Cambrian-Lower Ordovician carbonates in the northern Tarim Basin, China. Mar Pet Geol. 2016;72:295-316. https://doi.org/10.1016/j.marpe tgeo.2016.01.023.
Han Z, Xin WJ. Genetic mechanism and reservoir property of penecontemporary dolostones: the example of the major pay dolostons, Lower Paleozoic, Ordos region. Earth Sci Front (China Univ Geosci Beijing). 1995;2(3-4):226-47 (in Chinese).

He J, Fang SX, Hou FH, et al. Characteristics of karst reservoirs of Majiagou Formation (Middle Ordovician) in central gas-field area. Ordos Basin Oil Gas Geol. 2009;30(3):350-6 (in Chinese).

He XY, Shou JF, Shen AJ, et al. Geochemical characteristics and origin of dolomite: a case study from the middle assemblage of Ordovician majiagou formation member 5 of the west of jingbian gas field, ordos basin, North China. Pet Exp Dev. 2014;41:417-27. https://doi.org/10.1016/S1876-3804(14)60048-3.

Hips K, Haas J, Poros Z, et al. Dolomitization of Triassic microbial mat deposits (Hungary): origin of microcrystalline dolomite. Sed Geol. 2015;318:113-29. https://doi.org/10.1016/j.sedge o.2014.12.002.

Hou FH, Fang SX, Zhao JS, et al. Depositional environment model of Middle Ordovician Majiagou Formation in Ordos Basin. Mar Origin Pet Geol. 2002;07(1):38-46 (in Chinese).

Hsü KJ, Schneider J. Progress report on dolomitization hydrology of Abu Dhabi Sabkhas, Arabian Gulf. The Persian Gulf. Berlin: Springer; 1973. p. 409-22. https://doi.org/10.1007/978-3-64265545-6_20.

Huang SJ, Qing HR, Pei CR, et al. Strontium concentration, isotope composition and dolomitization fluids in the Feixianguan Formation of Triassic, Eastern Sichuan of China. Acta Pet Sin. 2006;22(8):2123-32 (in Chinese).

Huang SJ, Huang KK, Lü J, et al. The relationship between dolomite textures and their formation temperature: a case study from the Permian-Triassic of the Sichuan Basin and the Lower Paleozoic of the Tarim Basin. Pet Sci. 2014;11(1):39-51. https://doi. org/10.1007/s12182-014-0316-7.

Huang ZL, Bao HP, Ren JF, et al. Characteristics and Genesis of Dolomite in Majiagou Formation of Ordovician. South Ordos Basin Geosci. 2011;25(5):925-30 (in Chinese).

Irwin H, Curtis C, Coleman M. Isotopic evidence for source of diagenetic carbonates formed during burial of organic-rich sediments. Nature. 1977;269:209-13. https://doi.org/10.1038/269209a0.

Jiang L, Cai C, Worden RH, et al. Multiphase dolomitization of deeply buried Cambrian petroleum reservoirs, Tarim Basin, north-west China. Sedimentology. 2016;63:2130-57. https://doi.org/10.1111/ sed.12300.

Kaczmarek SE, Gregg JM, Bish DL, et al. Dolomite, very-high magnesium calcite, and microbes: implications for the microbial model of dolomitization, vol 109. Tulsa: SEPM Special Publication; 2017. p. 1-14.

Kelts K, Talbot M. Lacustrine carbonates as geochemical archives of environmental change and biotic/abiotic interactions. In: Large Lakes. Berlin: Springer; 1990. p. 288-315. https://doi. org/10.1007/978-3-642-84077-7_15.

Land LS, et al. The application of stable isotopes to studies of the origin of dolomite and to problems of diagenesis of clastic sediments. In: Arthur MA, Anderson TF, Kaplan IR, et al., editors. Stable isotopes in the sedimentary geology. SEPM short course notes. Tulsa: SEPM; 1983. p. 41-422.

Liu H, Ma T, Tan XC, et al. Origin of structurally controlled hydrothermal dolomite in epigenetic karst system during shallow burial: an example from middle Permian Maokou Formation, Central Sichuan Basin, SW China. Pet Explor Dev. 2016;43:1000-12. https://doi.org/10.1016/S1876-3804(16)30117-3.

Liu XS, Zhang DF, Dong GD, et al. Petrography and facies distribution of Middle Ordovician Ma $5_{1+2}$ tight dolomite reservoirs in the Ordos Basin, Central China. Energy Explor Exploit. 2019;37(1):473-92. https://doi.org/10.1177/0144598718806449. 
Liu Y, Tan XC, Liu XY, et al. Sedimentary characteristics and distribution of grain shoals of $\mathrm{Ma}_{7}$ submember in the Central Ordos Basin. Acta Sedimentol Sin. 2018;36(4):796-806 (in Chinese).

Lu ZY, Chen HD, Qing HR, et al. Petrography, fluid inclusion and isotope studies in Ordovician carbonate reservoirs in the Shunnan area, Tarim basin, NW China: implications for the nature and timing of silicification. Sed Geol. 2017;359:29-43. https://doi. org/10.1016/j.sedgeo.2017.08.002.

Mahboubi A, Nowrouzi Z, Al-Aasm IS, et al. Dolomitization of the Silurian Niur Formation, Tabas block, east central Iran: fluid flow and dolomite evolution. Mar Pet Geol. 2016;77:791-805. https:// doi.org/10.1016/j.marpetgeo.2016.07.023.

Mazzullo SJ. Organogenic dolomitization in peritidal to deepsea sediments. J Sediment Res. 2000;70:10-23. https://doi. org/10.1306/2DC408F9-0E47-11D7-8643000102C1865D.

Meister P, Mckenzie JA, Bernasconi SM, et al. Dolomite formation in the shallow seas of the Alpine Triassic. Sedimentology. 2013;60:270-91. https://doi.org/10.1111/sed.12001.

Meng FW, Zhang ZL, Yan XQ, et al. Stromatolites in Middle Ordovician carbonate-evaporite sequences and their carbon and sulfur isotopes stratigraphy, Ordos Basin, northwestern China. Carbonates Evaporites. 2019;34(1):11-20. https://doi.org/10.1007/s1314 6-017-0367-0.

Mountjoy EW, Achel HGM, Green D, et al. Devonian matrix dolomites and deep burial carbonate cements: a comparison between the Rimbey-Meadowbrook reef trend and the deep basin of westcentral Alberta. Bul Can Pet Geol. 1999;47:487-509. https://doi. org/10.35767/gscpgbull.47.4.487.

Nicolaides S. Marine-derived dolomite in the shallowly buried temperate port Campbell limestone (Miocene), Otway Basin, Australia. Sedimentology. 1997;44:143-57. https://doi. org/10.1111/j.1365-3091.1997.tb00429.x.

Nielsen P, Swennen R, Keppens E. Multiple-step recrystallization within massive ancient dolomite units: an example from the Dinantian of Belgium. Sedimentology. 1994;41:567-84. https:// doi.org/10.1111/j.1365-3091.1994.tb02011.x.

Perri E, Tucker M. Bacterial fossils and microbial dolomite in Triassic stromatolites. Geology. 2015;35:207-10. https://doi.org/10.1130/ G23354A.1.

Petrash DA, Bialik OM, Bontognali TR, et al. Microbially catalyzed dolomite formation: from near-surface to burial. Earth Sci Rev. 2017;171:558-82. https://doi.org/10.1016/j.earsc irev.2017.06.015.

Preuss A, Schauder R, Fuchs G, et al. Carbon isotope fractionation by autotrophic bacteria with three different $\mathrm{CO}_{2}$ fixation pathways. Zeitschrift Für Naturforschung C. 1989;44:397-402. https://doi. org/10.1515/znc-1989-5-610.

Radtke G, Golubic S. Microbial euendolithic assemblages and microborings in intertidal and shallow marine habitats: insight in cyanobacterial speciation. In: Joachim R, Nadia-Valerie Q, Gernot A, editors. Advances in stromatolite geobiology. Berlin: Springer; 2011. p. 233-64. https://doi.org/10.1007/978-3-642-10415-2_16.

Reinhold C. Multiple episodes of dolomitization and dolomite recrystallization during shallow burial in upper Jurassic shelf carbonates: eastern swabian alb, southern Germany. Sed Geol. 1998;121:71-95. https://doi.org/10.1016/S0037-0738(98)00077 $-3$.

Shi JA, Shao Y, Zhang SC, et al. Lithofacies paleogeography and sedimentary environment in Ordovician Majiagou Formation. Eastern Ordos Basin Nat Gas Geosci. 2009;20(3):316-24 (in Chinese).

Shinn EA. Tidal flat environments. In: Scholle PA, Bebout DG, Moore $\mathrm{CH}$, editors. Carbonate depositional environments, vol 33. Tulsa: AAPG Memoir; 1983. p. 171-210.

Smith LB Jr. Origin and reservoir characteristics of Upper Ordovician Trenton-Black River hydrothermal dolomite reservoirs in New York. AAPG Bull. 2006;90:1691-718. https://doi. org/10.1306/04260605078.

Su ZT, Chen HD, Xu FY, et al. Geochemistry and dolomitization mechanism of Majiagou dolomites in Ordovician, Ordos, China. Acta Pet Sin. 2011;27(8):2230-8 (in Chinese).

Taylor HPJ. Oxygen and hydrogen isotope relationships in hydrothermal mineral deposits. Geochemistry of hydrothermal ore deposits. New York: Wiley; 1997. p. 229-302.

Veizer J, Ala D, Azmy K, et al. ${ }^{87} \mathrm{Sr} /{ }^{86} \mathrm{Sr}, \delta^{13} \mathrm{C}$ and $\delta^{18} \mathrm{O}$ evolution of Phanerozoic seawater. Chem Geol. 1999;161:59-88. https://doi. org/10.1016/S0009-2541(99)00081-9.

Viladkar SG, Schidlowski M. Carbon and oxygen isotope geochemistry of the amba dongar carbonatite complex, Gujarat, India. Gondwana Res. 2000;3:415-24. https://doi.org/10.1016/S1342 $-937 X(05) 70299-9$.

Wan CL, Zhou YQ, Chen Y, et al. Deep fluid activity in middle and westernOrdos Basin, Northwest China and its heating effect on hydrocarbon generation in Ordovician. Earth Sci Front. 2006;13(3): 122-8 (in Chinese).

Wang BQ, Al-Aasm IS. Karst-controlled diagenesis and reservoir development: example from the Ordovician main-reservoir carbonate rocks on the eastern margin of the Ordos Basin, China. AAPG Bull. 2002;86(9):1639-58. https://doi. org/10.1306/61EEDD28-173E-11D7-8645000102C1865D.

Wang BQ, Qiang ZT, Zhang F, et al. Isotope characteristics of dolomite from the fifth member of the Ordovician Majiagou Formation, the Ordos Basin. Geochimica. 2009;38(5):472-9 (in Chinese).

Wang LC, Hu WX, Wang XL, et al. Seawater normalized REE patterns of dolomites in Geshan and Panlongdong sections, China: implications for tracing dolomitization and diagenetic fluids. Mar Pet Geol. 2014;56:63-73. https://doi.org/10.1016/j.marpe tgeo.2014.02.018.

Warthman R, Van Lith Y, Vasconcelos C, et al. Bacterially induced dolomite precipitation in anoxic culture experiments. Geology. 2000;28:1091-4. https://doi.org/10.1130/00917613(2000)28\%3c1091:BIDPIA\%3e2.0.CO;2.

Warren J. Dolomite: occurrence, evolution and economically important association. Earth Sci Rev. 2000;52:1-81. https://doi.org/10.1016/ S0012-8252(00)00022-2.

Weis D, Kieffer B, Maerschalk C, et al. High-precision isotopic characterization of USGS reference materials by TIMS and MC-ICPMS. Geochem Geophys Geosyst. 2006;7(8):1-30. https://doi. org/10.1029/2006GC001283.

Wolicka D, Borkowski A. Precipitation of $\mathrm{CaCO}_{3}$ under sulphatereduction conditions. In: Advances in stromatolite geobiology. Berlin: Springer; 2011. p. 151-60. https://doi.org/10.1007/9783-642-10415-2_10.

Xi SL, Xiong Y, Liu XY, et al. Sedimentary environment and sea level change of the subsalt interval of Member 5 of Ordovician Majiagou Formation in central Ordos Basin. J Palaeogeogr. 2017;19(5):773-90 (in Chinese).

Xia MJ, Zhen CB, Dai JX, et al. Ordovician under-salt reservoirs and forming conditions of gas poolsin in eastern Ordos Basin. Nat Gas Geosci. 2007;18(2):204-8 (in Chinese).

Xiao D, Tan XC, Xi AH, et al. An inland facies-controlled eogenetic karst of the carbonate reservoir in the Middle Permian Maokou Formation, southern Sichuan Basin, SW China. Mar Pet Geol. 2016;72:218-33. https://doi.org/10.1016/j.marpe tgeo.2016.02.001.

Xiao D, Tan XC, Fan LY, et al. Reconstructing large-scale karst paleogeomorphology at the top of the Ordovician in the Ordos Basin, China: control on natural gas accumulation and paleogeographic implications. Energy Sci Eng. 2019;7:3234-54. https://doi. org/10.1002/ese3.494. 
Xiao D, Tan XC, Zhang DF, et al. Discovery of syngenetic and eogenetic karsts in the Middle Ordovician gypsum-bearing dolomites of the eastern Ordos Basin (central China) and their heterogeneous impact on reservoir quality. Mar Pet Geol. 2019;99:190-207. https ://doi.org/10.1016/j.marpetgeo.2018.10.004.

Xiao D, Cao J, Luo B, et al. On the dolomite reservoirs formed by dissolution: differential eogenetic versus hydrothermal in the lower Permian Sichuan Basin, southwestern China. AAPG Bull. 2020;104(7):1405-38. https://doi.org/10.1306/02262018242.

Xie JL, Wu XN, Sun LY, et al. Lithofacies palaeogeography and potential zone prediction of Ordovician Majiagou Member-5 in Ordos Basin. Mar Origin Pet Geol. 2013;18(4):23-32 (in Chinese).

Xiong Y, Tan XC, Dong GD, et al. Diagenetic differentiation in the Ordovician Majiagou Formation, Ordos Basin, China: facies, geochemical and reservoir heterogeneity constraints. J Pet Sci Eng. 2020;191:107179. https://doi.org/10.1016/j.petrol.2020.107179.

Xiong Y, Tan XC, Zuo ZF, et al. Middle Ordovician multi-stage penecontemporaneous karstifcation in North China: implications for reservoir genesis and sea level fluctuations. J Asian Earth Sci. 2019;183:103969. https://doi.org/10.1016/j.jseaes.2019.103969.

Yang XY, Mei QY, Wang XZ, et al. Indication of rare earth element characteristics to dolomite petrogenesis - a case study of the fifth member of Ordovician Majiagou Formation in the Ordos Basin, central China. Mar Pet Geol. 2018;92:1028-40. https:// doi.org/10.1016/j.marpetgeo.2017.12.004.

Yao JL, Wang BQ, Wang Y, et al. Geochemical characteristics of dolomites in Lower Ordovician Majiagou Formation. Ordos Basin Acta Sedimentol Sin. 2009;27(3):381-9 (in Chinese).

Zhang YS, Xing EY, Wang ZZ, et al. Evolution of lithofacies paleogeography in the Ordos Basin and its implication of Potash Formation. Acta Geol Sin. 2015;89(11):1921-35 (in Chinese).

Zhao JX, Chen HD, Zhang JQ, et al. Genesis of dolomite in the fifth member of Majiagou Formation in the middle Ordos Basin. Acta Pet Sin. 2005;26(5):38-41 (in Chinese). 